\title{
Step-changes in the physical, chemical and biological characteristics of the Gulf of Maine, as documented by the GNATS time series
}

\author{
W. M. Balch ${ }^{1, *}$, D. T. Drapeau ${ }^{1}$, B. C. Bowler ${ }^{1}$, T. G. Huntington ${ }^{2}$ \\ ${ }^{1}$ Bigelow Laboratory for Ocean Sciences, 60 Bigelow Dr., PO Box 380, East Boothbay, Maine 04544, USA \\ ${ }^{2}$ USGS Augusta, US Geological Survey, 196 Whitten Rd., Augusta, Maine 04330, USA
}

\begin{abstract}
We identify step-changes in the physical, chemical and biological characteristics of the Gulf of Maine (GoM) using the Gulf of Maine North Atlantic Time Series (GNATS), a series of oceanographic measurements obtained between September 1998 and December 2010 along a transect in the GoM running from Portland, ME, to Yarmouth, NS. GNATS sampled a period of extremes in precipitation and river discharge ( 4 of the 8 wettest years of the last century occurred between 2005 and 2010). Coincident with increased precipitation, we observed the following shifts: (1) decreased salinity and density within the surface waters of the western GoM; (2) both reduced temperature and vertical temperature gradients in the upper $50 \mathrm{~m}_{i}(3)$ increased colored dissolved organic matter (CDOM) concentrations and particle scattering in the western $\mathrm{GoM}_{i}(4)$ increased concentrations of nitrate and phosphate across all but the eastern GoM; (5) increased silicate, particularly in the western GoM, with a sharp increase in the ratio of silicate to dissolved inorganic nitrogen; (6) sharply decreased carbon fixation by phytoplankton; (7) moderately decreased chlorophyll, particulate organic carbon (POC) and particulate inorganic carbon (PIC) in the central GoM and (8) decreased POC- and PIC-specific growth rates. Gulf-wide anomaly analyses suggest that (1) the surface density changes were predominantly driven by temperature, (2) dissolved nutrients, as well as POC/PON, varied in Redfield ratios and (3) anomalies for salinity, density, CDOM, particle backscattering and silicate were significantly correlated with river discharge. Precipitation and river discharge appear to be playing a critical role in controlling the long-term productivity of the Gulf of Maine by supplying CDOM and detrital material, which ultimately competes with phytoplankton for light absorption.
\end{abstract}

KEY WORDS: Gulf of Maine $\cdot$ Climate change $\cdot$ Phytoplankton primary production

\section{INTRODUCTION}

\section{Coastal waters - continuum from land to sea}

Coastal marine environments are characterized by strong hydrographical, chemical, biological and bio-optical gradients. As such, they represent a mixing continuum from land to sea. The combination of shallow depths, tidal influence, storm- induced mixing and additions of buoyant fresh water from rivers make coastal systems complicated and difficult to predict in space and time. This complexity reaches into biogeochemistry; from a carbon perspective, it is still not known whether coastal systems are sources or sinks for carbon (King et al. 2007).

One of the most challenging contemporary scientific problems is to model the global carbon 
cycle and the influence of humans on it. Our knowledge of the individual components of the global carbon cycle is improving but is still rudimentary (Denman et al. 2007). Carbon cycling, storage and transport in coastal marine systems have become critical issues in global change science (Karl et al. 2009). While changes in the riverine export of carbon from watersheds have been observed in North America and Europe, identifying the key drivers for these changes, especially those associated with climate, has been problematic (Raymond \& Oh 2007).

The most synoptic method for sampling large areas of coastal waters is remote sensing. For visible-band remote sensing, coastal marine optics are complex (Mobley 1994), mainly due to the introduction of blue-absorbing humic materials via rivers, intense blooms of blue-green absorbing phytoplankton and regular, energetic resuspension of sediment particles via tides, waves, wind-driven mixing and strong boundary-layer advection along the land-sea boundary. Coastal waters are characterized by strong gradients and abundant frontal boundaries, which make it difficult to differentiate time-dependent change from spatial variability within an advecting field, using time series based on a single mooring or station. This is why multistation or transect time series - repeated runs of a transect - are critical in coastal time series to document change in coastal waters and for better definition of spatially varying water mass boundaries. Moreover, because of the high spatial and temporal variability observed in coastal waters, climate change impacts on the coastal environment require time series of sufficient length to increase the statistical power and discern the signal through the considerable interannual noise. Adding to the problem of defining long-term change is the nature of climate change itself, typically characterized by nonlinear, threshold-style change instead of long-term gradual change (Schmittner \& Weaver 2001, Rial et al. 2004, Walther 2010). The same problems with documenting past significant change in coastal environments are manifest when modeling future changes.

One coastal ecosystem subject to considerable climate change is the Gulf of Maine (Pershing et al. 2001), with strong terrestrial and ocean inputs of dissolved and particulate carbon. Given the strong connections between land and ocean in this shelf sea, it is necessary to review both the Gulf of Maine as well as the physiography of its surrounding watersheds.

\section{Gulf of Maine (GoM) watersheds}

The physiography of Maine and New Brunswick is characterized by hilly to mountainous plateau terrain in the western sections and hilly lowlands in the central and southeastern coastal region (Toppan 1935, Rampton et al. 1984). The climate is humid continental (Peel et al. 2007), and precipitation ranges from $\sim 0.9 \mathrm{~m} \mathrm{yr}^{-1}$ in the north to as much as $1.20 \mathrm{~m} \mathrm{yr}^{-1}$ in the coastal sections (Prism Group, Oregon State University, http://prism.oregonstate.edu, accessed 19 October 2009). The liquid precipitation is relatively evenly distributed over the seasons. The annual snowfall ranges from $\sim 1.50 \mathrm{~m} \mathrm{yr}^{-1}$ in the southern and coastal sections to $>2.0 \mathrm{~m} \mathrm{yr}^{-1}$ in the inland regions (Cember \& Wilks 1993). The typical seasonal pattern of streamflow shows a distinct spring peak during snowmelt, with lowest flows during late summer and early fall (Hodgkins \& Dudley 2005). The runoff, or water yield (rainfall minus evapotranspiration), ranges from $55 \%$ to $65 \%$ of rainfall inputs (Randall 1998). While major GoM watersheds have been gauged (in both US and Canadian territories), there has been only sporadic (not long-term, continuous) characterization and monitoring of water quality.

The total area of the watershed draining into the GoM is $179000 \mathrm{~km}^{2}$, within which there are 25 watersheds. The total discharge into the GoM is estimated to be $\sim 3000 \mathrm{~m}^{3} \mathrm{~s}^{-1}$ (Meade \& Emery 1971). Fourteen watersheds contribute $\sim 50 \%$ of the freshwater influx. The St. John River is the largest river flowing into the GoM, draining an area of $\sim 55000 \mathrm{~km}^{2}$, with an average daily discharge of $\sim 990 \mathrm{~m}^{3} \mathrm{~s}^{-1}$. The Penobscot River, ME, is the second largest river in New England, draining a $20109 \mathrm{~km}^{2}$ watershed (Fig. 1). The average discharge is $\sim 341 \mathrm{~m}^{3} \mathrm{~s}^{-1}$, peaking in March to April with a second peak from November to December.

Maine watersheds are primarily composed of forested land ( 89\%) (Griffith \& Alerich 1996). Of the remaining land, $5 \%$ is covered by $\sim 5700$ lakes, swamps and ponds $>0.4 \mathrm{ha}$, and $4 \%$ is used for agriculture. Palustrine wetlands occupy $\sim 26 \%$ of the land area in Maine; $60 \%$ of these wetlands are forested, and the remainder are covered by scrub/shrub or emergent vegetation. Of the organic carbon transported in Maine (plus New Brunswick and Nova Scotia) rivers, $\sim 90 \%$ is in the form of DOC (Wetzel 1975), with concentrations typically ranging from 4 to $15 \mathrm{mg} \mathrm{Cl}^{-1}$, lowest in winter and spring regardless of the level of discharge, higher in summer (lowor high-flow periods) and highest in fall (high-flow periods) (also observed by Cronan et al. 1999). 


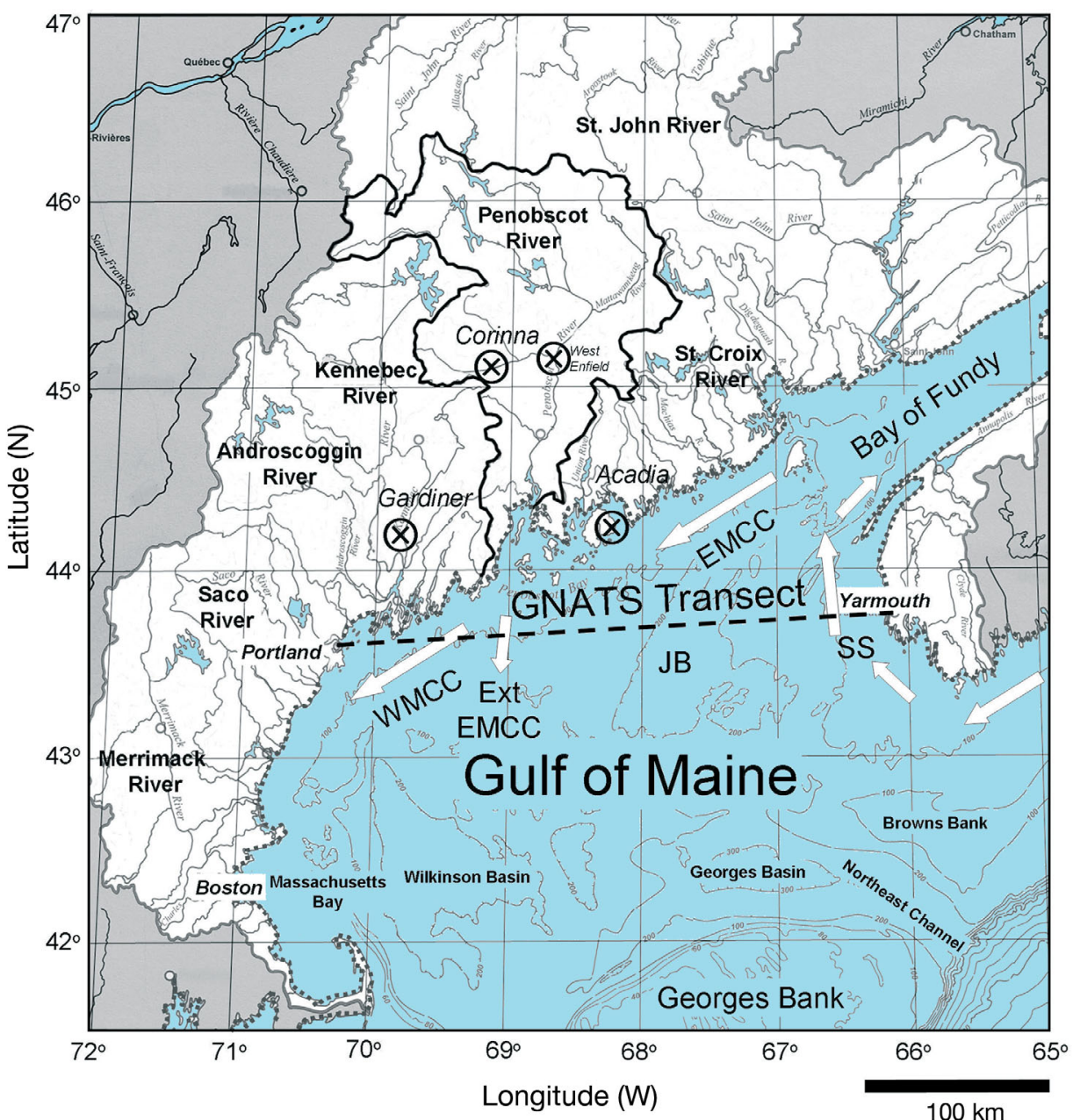

Fig. 1. Region of study showing the Gulf of Maine bathymetry and the terrestrial watersheds draining into it (white; 8 major watersheds are the Merrimack, Saco, Androscoggin, Kennebec, Penobscot [solid black outline], St. Croix, St. John and Clyde/ Annapolis/Yarmouth watersheds) as well as watersheds that do not drain into it (gray). $\otimes$ : Locations of 3 weather stations from which temperature and precipitation data were collected (Gardiner, Corinna and Acadia, ME) and the site where the Penobscot River discharge was measured (W. Enfield, ME). The GNATS transect (dashed line) crosses the Gulf of Maine between Portland, ME, and Yarmouth, NS. Water masses that are traversed along the transect are also indicated: Western Maine Coastal Current (WMCC), Eastern Maine Coastal Current (EMCC), Extension of the Eastern Maine Coastal Current (Ext EMCC), Jordan Basin (JB) and Scotian Shelf Water (SS). The coastline (dotted line) and important bathymetric features (banks and basins) are also designated. General mean surface current flow is shown with white arrows
Century-long time series have been collected for specific watersheds, such as the Penobscot watershed (with a 107-yr record of meteorological and discharge data). Accumulating evidence suggests that anthropogenic-induced climate change has resulted in a more intense hydrological cycle, manifested in increasing rates of evaporation and precipitation during the 20th century (Huntington 2006). Many river basins, including those draining to the GoM, have had increasing runoff and more intense rainfall (Walter et al. 2004, Keim et al. 2005, Hayhoe et al. 2007, Madsen \& Figdor 2007), with longer intervening dry periods (Groisman \& Knight 2008). There is also evidence for an increase in the magnitude of floods in New England during the last 75 yr (Collins 2009).

\section{Gulf of Maine}

The GoM is a semi-enclosed shelf sea, with deepest depths of $370 \mathrm{~m}$. There is one location, the Northeast Channel, where either North Atlantic Slope
Water (NASW) or Labrador Sea Water (LSW) can enter into the GoM, over a sill (230 m deep) (Fig. 1). Periods of inflow have been observed over 3 to 7 -wk periods (Ramp et al. 1985). Flows through the Northeast Channel are not steady through time and can reverse (Pettigrew et al. 2011). The GoM has traditionally supported a productive fishery due to high rates of primary production (O'Reilly \& Busch 1984, Balch et al. 2008). The mean surface circulation is geostrophic and primarily counterclockwise. Water enters the GoM from the Scotian shelf around the southern flank of Nova Scotia, looping northward into the Bay of Fundy, where it is mixed by strong tidal currents with the buoyant outflow of the St. John River. It then heads southwestward as the Eastern Maine Coastal Current (EMCC) (Fig. 1) (Brooks 1985). Some of the along-shelf flow veers offshore near Penobscot Bay as the Extension of the Eastern Maine Coastal Current (ExtEMCC) (Brooks \& Townsend 1989, Pettigrew et al. 1998). To the south of Penobscot Bay, the Maine coastal current continues in a southwestward direction as the Western 
Maine Coastal Current (WMCC) (Xue et al. 2000). Long-term nutrient observations near the Northeast Channel suggest the possible alternating influence of high-salinity, warm North Atlantic Slope Water (NASW) versus colder, fresher, silicate-rich Labrador Sea Water (LSW) flowing into the GoM, and this could have ramifications for the overall productivity and abundance of specific functional groups, such as diatoms and dinoflagellates (Thomas et al. 2003, Townsend et al. 2005, 2010). Ji et al. (2008) have suggested, using ocean-color remote sensing plus 100-m-deep hydrographic measurements, that an increasing influence of lower salinity water (originating in the LSW and Nova Scotian shelf) is the cause of earlier spring blooms because the added stratification stabilizes the water column earlier. It also impedes the upward mixing of nutrients, hence inducing a westward temporal progression of phytoplankton blooms from the Scotian Shelf (SS) waters into the eastern GoM and ultimately western GoM. Chlorophyll a ( $\mathrm{chl}$ a) concentrations are highest near the coastal boundaries, dropping in the middle Gulf, and they show an annual cycle with a March spring bloom (associated with vernal warming and shallowing mixed layers) and a fall bloom (associated with renewed mixing and turnover) (Thomas et al. 2003).

\section{Gulf of Maine time series}

Two sets of time series observations in the GoM are the Gulf of Maine Ocean Observing System (GOMOOS) (Pettigrew et al. 2008) and the Gulf of Maine North Atlantic Time Series (GNATS) (Balch et al. 2004). The former consists of buoy measurements of mostly physical data along the Maine coast with one mooring in Jordan Basin. The latter is a roughly eastwest transect time series across the GoM at $43.75^{\circ} \mathrm{N}$, begun in 1998, operating from late spring to early fall on ships of opportunity (mainly seasonal ferries) until 2006, then year-round thereafter using other vessels in the winter months. Complete details of the route and variables sampled can be found in earlier work (Balch et al. 2004, 2008). GNATS data consist of both continuous measurements for hydrography and an entire suite of inherent optical properties (spectral absorption, scattering and attenuation) and apparent optical properties (spectral above-water radiometry). Discrete samples were taken from a flowing seawater system for chemistry (nutrients) and biology (pigments, phytoplankton cell counts, particulate organic/ inorganic carbon, biogenic silica, ${ }^{14} \mathrm{C}$-primary production, ${ }^{14} \mathrm{C}$-calcification, cell counts and particle size distribution). Vertical profiles of temperature were also made at all of the discrete stations using expendable bathythermographs (XBT) and/or Moving Vessel Profiler deployments (Brook Ocean Technology) to measure temperature, salinity and chlorophyll fluorescence as a function of depth. Since 2008, a Slocum electric glider has been deployed seasonally (approximately 4 times per year) along the GNATS line to better understand the vertical distribution of optical and hydrographic properties. Weather forecasting was used to plan GNATS trips to coincide with clearsky days to synchronize with ocean color and thermal-band satellite measurements, which allows better extrapolation of the transect measurements to the entire Gulf. We also gathered other historical datasets from this same transect to extend GNATS analyses further back in time.

\section{The Gulf of Maine: a highly-documented continuum from land to sea}

Here, we begin with a description of century-long climate records for temperature and precipitation, taken at 3 independent weather stations in and around the Penobscot watershed in Maine, the second largest watershed in the region. We also include a century-long time series of Penobscot River discharge to show the nature of freshwater discharge into the GoM. This is provided as a backdrop for describing the decadal trends in the GNATS data, in which we present the ship-based hydrographic, chemical, biological and bio-optical trends for the 12.3-yr (hereafter 12-yr) data record between September 1998 and December 2010. We will address the question of the space-time distributions of properties along the transect, as well as monthly Gulfwide anomalies. Interrelationships among the various anomalies will be analyzed as we explore the linkages within this complex ecosystem as well as the influence of freshwater discharge from the terrestrial watersheds surrounding the Gulf. Discussions of the phytoplankton enumeration, particle size and the glider data will be presented elsewhere.

\section{METHODS}

\section{Climatological data}

To frame the physical, chemical, biological and biooptical variability of the GoM, we used observations from the US Historical Climatology Network (http:// 
cdiac.ornl.gov/epubs/ndp/ushcn/ushcn.html). Data were accessed for 3 weather stations in Maine (Fig. 1): Gardiner, Corinna and Acadia. These stations were chosen because they are on either side of the Penobscot watershed (Gardiner and Acadia) as well as within this watershed (Corinna). Data specifics are discussed elsewhere (Peterson \& Vose 1997, Vose et al. 1998); all 3 weather stations recorded air temperature data from 1895 to 2009 inclusive. Mean annual precipitation was also documented for the same time period. Annual streamflow data were available for $107 \mathrm{yr}$ from the US Geological Survey (USGS) stream gauge on the Penobscot River at West Enfield, ME (station ID no. 01034500). These data were accessed from the National Water Information System (NWIS) online database, http://nwis.waterdata.usgs.gov/nwis/sw, on 26 October 2011.

\section{GNATS description}

GNATS sampling between Portland, ME, and Yarmouth, Nova Scotia, has been described previously (Balch et al. 2008), with trips performed monthly to semi-monthly. The only difference to note here is that winter cruises began in February 2006 (i.e. the time series became year-round). Nonetheless, there were occasional gaps of as much as 2 mo between ship trips during the winter due to unsafe wintertime sea-states. Previously, the sampling was performed aboard the MS 'Scotia Prince' ferry between May and October, concurrent with its seasonal schedule. The operations were moved to a high-speed catamaran ferry, MV 'The CAT', in fall 2006. During the months with no ferry, the sampling was performed on 3 vessels: FV 'Ella \& Sadie', RV 'Argo-Maine' and RV 'Connecticut'. In fall 2009, the ferry MV 'The CAT' stopped running, and the sampling thereafter was performed from the RV 'Argo-Maine' and RV 'Connecticut'.

\section{Calculation of space-time variability and Gulf-wide anomalies}

Spatial and temporal changes in the GNATS data were observed using Hövmoller plots, with time on the $y$-axis and longitude (for the nearly east-west ship transect) on the $x$-axis. The kriging parameters used for contouring the Hövmoller plots are described elsewhere (Balch et al. 2008). Data for analyses of anomalies were averaged across the entire GNATS transect. Gulf-wide anomalies were calculated by first binning the data from each cruise into monthly averages estimated from the entire 12-yr database, then comparing the mean for any single month with the monthly mean for the entire dataset. For example, the Gulf-wide anomaly for June 2002 was calculated by comparing the mean for all of the cruises performed during June 2002 with the mean of all of the June GNATS cruises.

\section{Inclusion of historical data in the GNATS database}

To examine variability along the GNATS transect over longer time scales, historical data for temperature, salinity and chl $a$ were obtained from 3 sources. (1) Charles Yentsch and David Phinney (Bigelow Laboratory, unpubl.) sampled between July 1978 and January 1981. (2) Carl Boyd (Dalhousie University) (Boyd 1985) sampled between June 1981 and November 1982 (see also Bisagni et al. 1996). Both of these datasets were acquired approximately monthly from the MV 'Marine Evangeline' ferry running along the GNATS transect. Expendable bathythermograph observations were also available from these datasets to calculate vertical temperature gradients over the upper $50 \mathrm{~m}$ of the water column. (3) The NOAA Marine Resources Monitoring, Assessment and Prediction (MARMAP) database (1977 to 1987) (Campbell \& O'Reilly 1988, Mountain \& Manning 1994) was also sub-sampled for temperature, salinity and chl a at locations within $\pm 5 \mathrm{~km}$ of the GNATS sample line.

\section{RESULTS}

\section{Climatological changes}

Data from the US Historical Climate Network demonstrate statistically significant increases in air temperature over the century. The combined data from all 3 stations (Fig. 2a) showed a moderate correlation between temperature and year, but the relationship was nonetheless highly significant (Fig. 2a, Table 1, Eq. ' $a$ '; henceforth, references to the equations in Table 1 will be followed by the letter designating the appropriate row of the table, e.g. Table 1a); the units and associated statistics for each equation (e.g. standard error for each fit parameter, correlation coefficient, F-statistic, degrees of freedom, and probability of computing these fits by chance) are provided in Table 1. The overall slope translated to about $+1.1^{\circ} \mathrm{C}$ per century, and there appeared to be a change in the slope in the late 1950s. There was also strong covariance of the temperature records. For ex- 


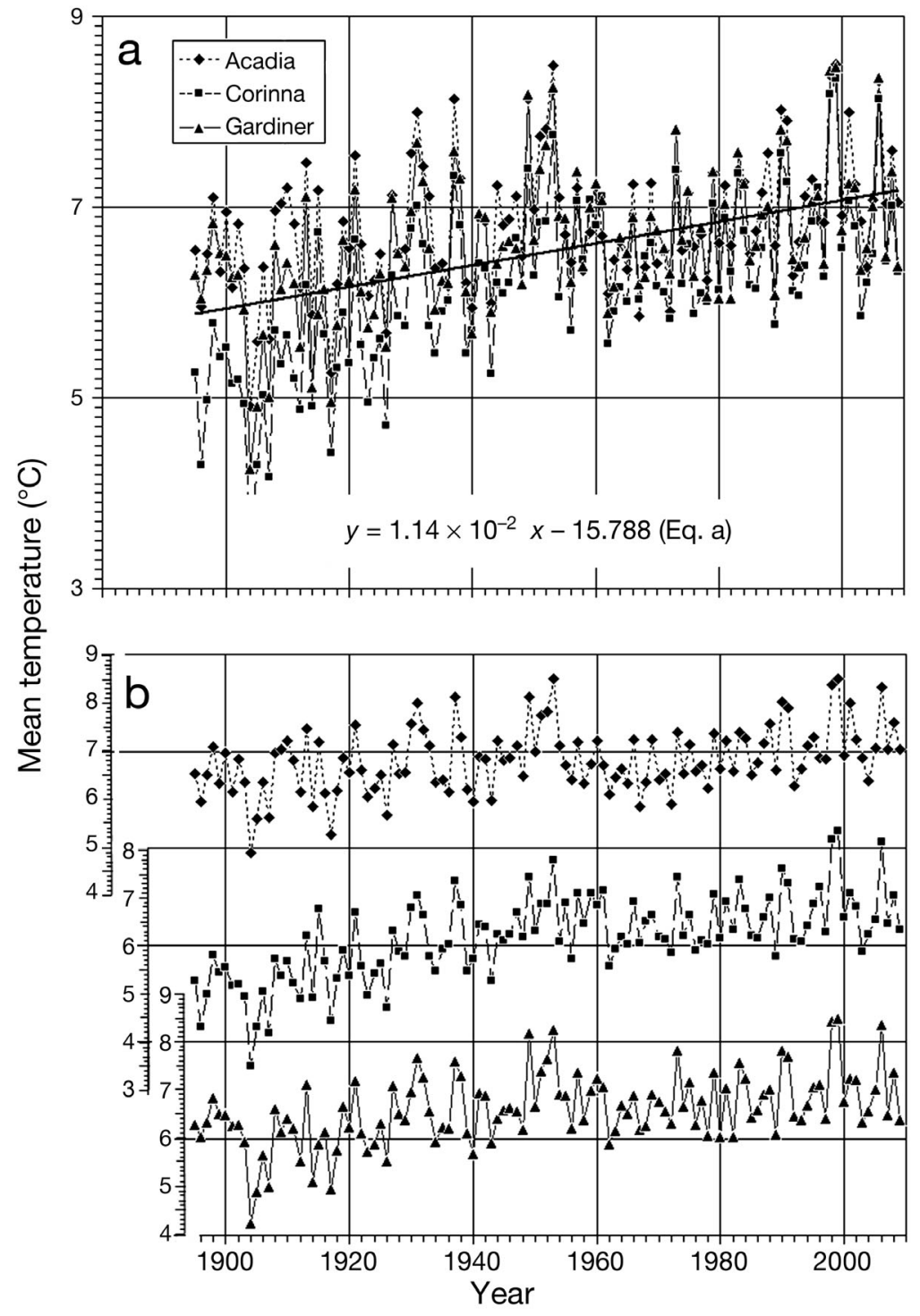

Fig. 2. (a) Annual mean temperature at 3 weather stations, 2 flanking (Acadia and Gardiner, ME) and 1 within the Penobscot watershed, from 1895 to 2009. Data are from the United States Historical Climatology Network (NOAA, National Climatic Data Center). The least-squares fit equation is shown; standard error for each statistically fit variable, statistical correlation, $F$-statistic, degrees of freedom (df) and the probability of the statistical fit by chance (p) are given in Table 1 for this and subsequent figures. (b) Mean temperature records from panel a, separated on the Y axis to better show the covariance of individual records

ample, the temperatures at Acadia $\left(T_{\text {Acadia }}\right)$ and Corinna ( $\left.T_{\text {Corinna }}\right)$ showed strong correlation to the temperature at Gardiner ( $\left.T_{\text {Gardiner }}\right)$ (Table $1 \mathrm{~b}, \mathrm{c}$, respectively). This high correlation can be seen in the comparison of the individual data records where peaks and troughs typically aligned (Fig. $2 \mathrm{~b}$ ).

Precipitation showed no significant changes in trend over the century (Fig. 3a) at any of the 3 sites individually $(p>0.05)$. For all 3 weather stations, the mean precipitation was $1.18{\mathrm{~m} \mathrm{yr}^{-1}}^{-1}$ (median $=1.15 \mathrm{~m} \mathrm{yr}^{-1}, \mathrm{SD}=0.23 \mathrm{~m} \mathrm{yr}^{-1}$, $\mathrm{df}=345, \max .=1.89 \mathrm{~m} \mathrm{yr}^{-1}$, min. $=$ $0.66 \mathrm{~m} \mathrm{yr}^{-1}$ ). Moreover, when all of the data for the 3 sites were combined, there was a low and barely significant correlation between total annual precipitation $\left(\mathrm{m} \mathrm{yr}^{-1}\right)$ and year $(\mathrm{p}<0.02)$ (Table $\left.1 \mathrm{~d}\right)$. While the absolute total annual precipitation had little significant change over the century, the variance in mean decadal precipitation almost doubled over the sampling period (Fig. 3b). The variance in decadal precipitation and year showed a moderate correlation, which was highly significant (Table 1e).

The GNATS stations were sampled through extremes in precipitation. During the 12-yr period of observation, 4 of the 8 highest annual rainfall years in over a century occurred at the Gardiner, ME, station, with total annual precipitation (including precipitable water from snowfall) $>1.4 \mathrm{~m} \mathrm{yr}^{-1}$ in 2005, 2006, 2008 and 2009. Moreover, the highest precipitation year since 1895 occurred in 2005 (Fig. 3a), also during the GNATS sampling period. Lastly, the third driest year in over a century was in 2001. The discharge at the W. Enfield station on the Penobscot (Fig. 3c) showed peaks and troughs that were well synchronized with the precipitation measured at the Corinna weather station, within the Penobscot watershed (Fig. 3a). Indeed, the precipitation and discharge records were correlated with an $\mathrm{r}^{2}$ of 0.65 (Fig. 3d, Table 1f), with a highly significant linear, least-squares relationship.

\section{GoM hydrographic changes}

The sea surface temperature (SST), temperature gradient over the top $50 \mathrm{~m}$, salinity and density all showed strong changes after 2005 (Fig. 4). Temporally, the summer SST values in the Western Maine Coastal Current (WMCC) were 13 to $15^{\circ} \mathrm{C}$ prior to 2005 , but then dropped $\sim 1^{\circ} \mathrm{C}$ from 2005 to 2008. In 2010, the waters showed a warming trend towards pre-2005 values (Fig. 4a). The Hövmoller plots contoured data with a spatial scale of 0.1 degree of longitude $(\sim 8 \mathrm{~km}$ at the latitude of GNATS; $x$-axis) and $14 \mathrm{~d}$ ( $y$-axis); thus, the step-change in 


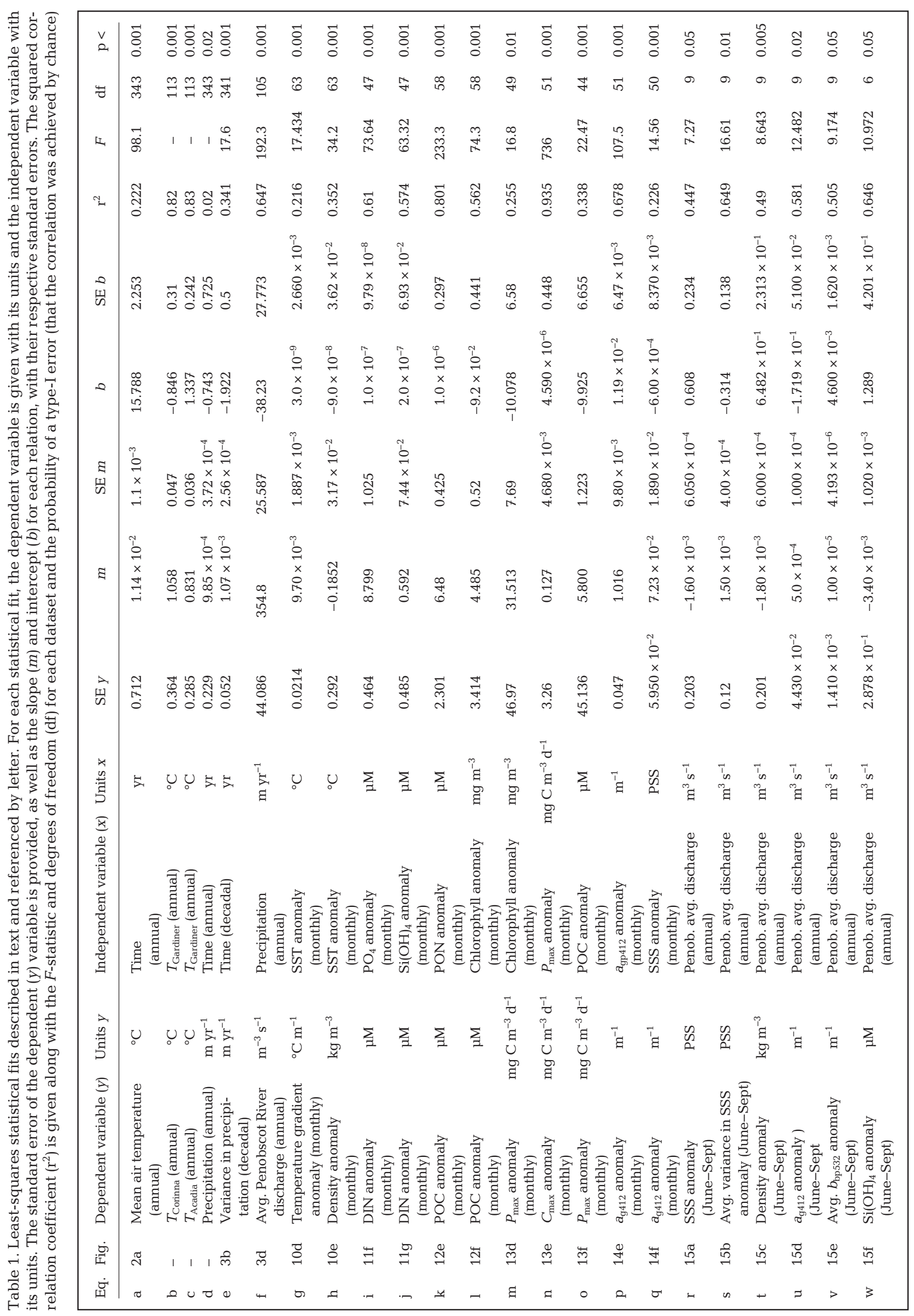


temperature was not related to the inclusion of winter data beginning in February 2006. Indeed, to verify this, the same kriging analysis was performed for only the data from May to October in the Hövmoller plots for all years, and the same step-change in tem-
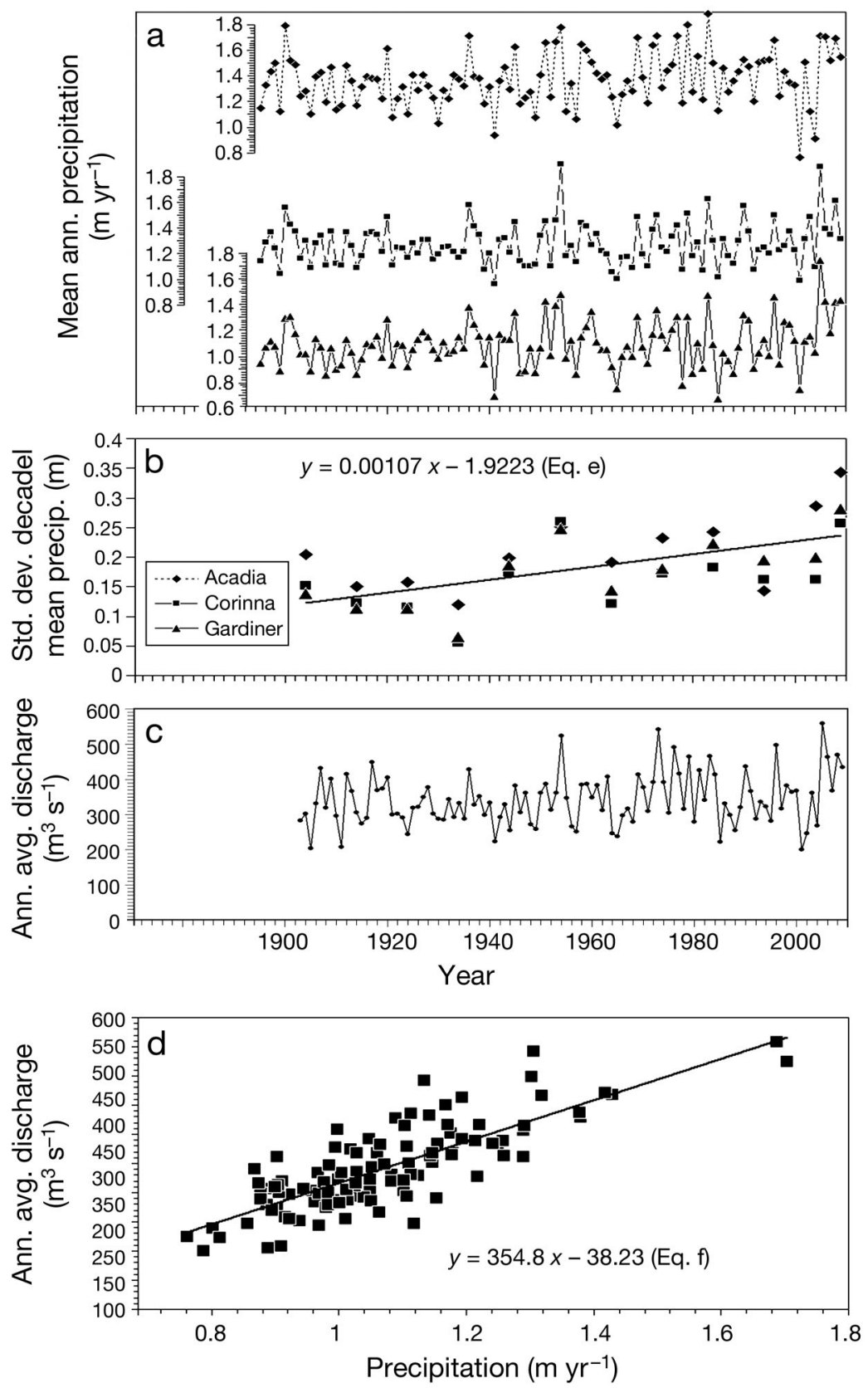

Fig. 3. (a) Annual mean precipitation at the same 3 weather sites shown in Fig. 1, with offset $y$-axes. (b) Standard deviation of decadal mean precipitation since 1895. Least-square linear fit equation, line and statistics shown. (c) Annual average discharge of Penobscot River at West Enfield, ME (in $\mathrm{m}^{3} \mathrm{~s}^{-1}$ ), beginning in 1903. Time scale ( $\mathrm{x}$-axis) of this panel aligns with the above panels. (d) Scattergram of annual average discharge at W. Enfield, ME $\left(\mathrm{m}^{3} \mathrm{~s}^{-1}\right)$, versus annual average precipitation at Corinna, $\mathrm{ME}$

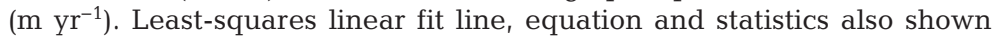

perature was observed (results not shown). Spatially, the Hövmoller plots show that warm, salty surface water characterized the middle of Jordan Basin (JB), while cooler, fresher water characterized the waters of the SS and ExtEMCC (Fig. 4a).

Vertical temperature gradients over the top $50 \mathrm{~m}$ showed variability in both space and time (Fig. 4b). Spatially, the results showed lower vertical temperature gradients in SS and ExtEMCC waters than in the JB. Temporally, vertical temperature gradients in the period between late fall and early spring were lower than in the period from late spring to early fall. Moreover, temperature gradients in the JB were typically 0.15 to $0.2^{\circ} \mathrm{C} \mathrm{m}^{-1}$ near the summer solstice (Fig. $4 \mathrm{~b})$, but in 2005, the JB summertime vertical temperature gradients dropped to $0.1^{\circ} \mathrm{C} \mathrm{m}^{-1}$. While the $50 \mathrm{~m}$ temperature gradient also appeared to decrease in the SS water after 2006, there were relatively few data points on which to base this conclusion due to logistics of sampling. Salinity showed the largest decreases (to 26 PSS) in the ExtEMCC and WMCC after 2005, which continued through 2010 (Fig. 4c).

The net effect of the temperature and salinity changes was that the density of JB surface waters in the summer months increased $\sim 1 \sigma_{\mathrm{q}}$ unit $\left(1 \mathrm{~kg} \mathrm{~m}^{-3}\right)$ in 2006 (Fig. 4d), and the lowest density water of the GNATS time series was observed in the WMCC from 2008 to 2010.

\section{Nutrient changes}

Nutrients were measured in GNATS beginning in late spring of 2002 and increased dramatically in 2007. Dissolved inorganic nitrogen (DIN; here including only nitrate plus nitrite) increased 10- to 30-fold in the JB, ExtEMCC and WMCC. Values in the SS water on the eastern side of the GoM did not show this change (Fig. 5a). Phosphate also mirrored this trend but increased $\sim 2.5$-fold in the WMCC, ExtEMCC and JB and did not change in the SS waters. Silicate showed a different pattern, however, with concentra- 

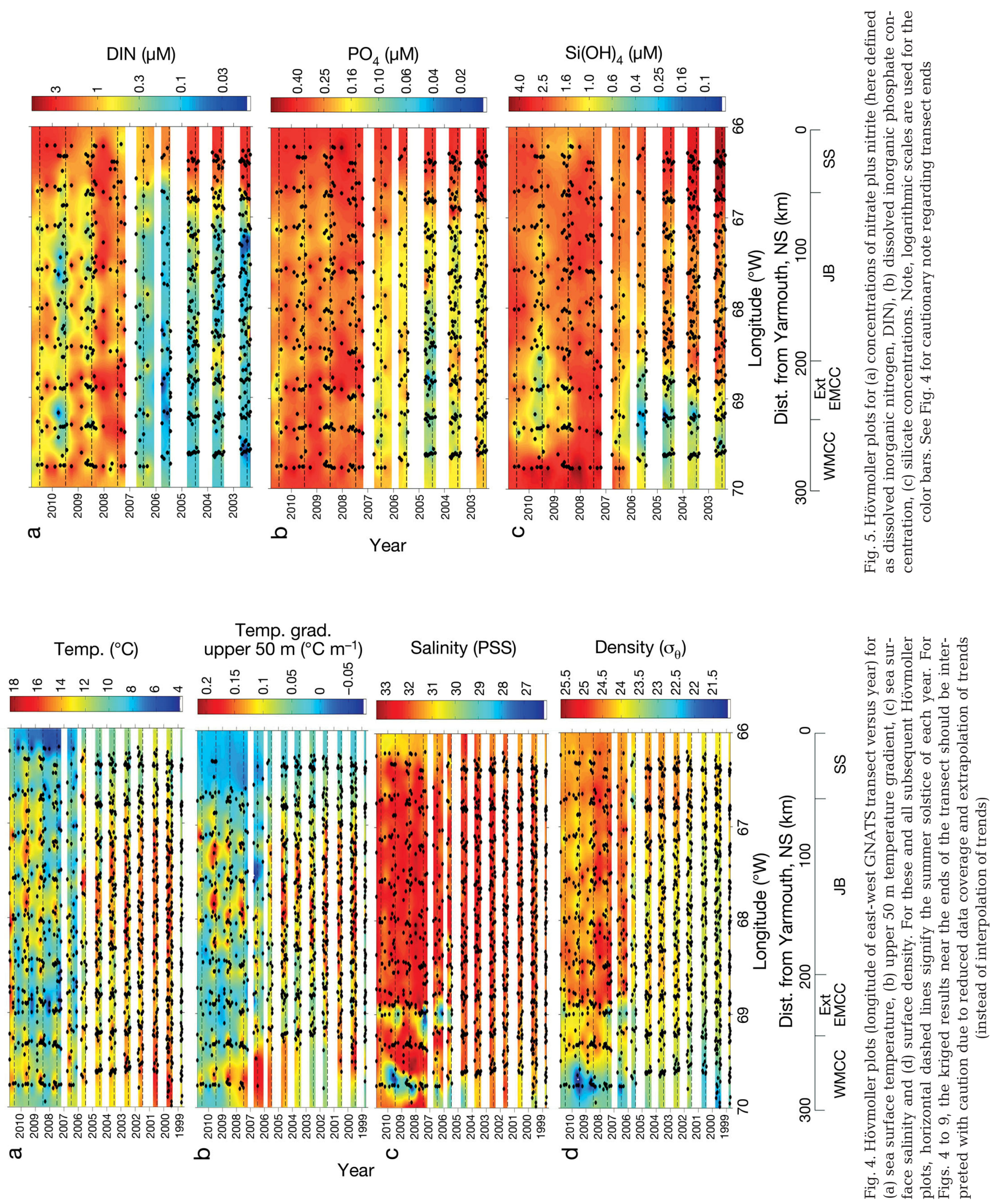
tions essentially similar over the time series in JB and SS waters, with a dramatic overall increase of $\sim 4$-fold in the ExtEMCC and WMCC waters, from 0.4 to $1.6 \mu \mathrm{M}$. Indeed, elevated silicate values were observed in 2008 and 2009 in the WMCC (Fig. 5c).

\section{Biological changes}

The standing stock of phytoplankton (as chlorophyll biomass and total particulate organic carbon [POC]) generally decreased after 2005. For chl a concentration, the decline was subtle and visible mostly in the JB and SS waters. The elevated chlorophyll, which characterized the frontal boundary between JB and SS waters $\left(66.7^{\circ} \mathrm{W}\right)$ from 1999 to 2004 , decreased in magnitude thereafter (Fig. 6a; note logarithmic color scale bar). Moreover, while extracted chl a concentrations in JB waters were 1 to $3 \mu \mathrm{g} \mathrm{l}^{-1}$ prior to 2005, post-2005 concentrations were typically $\sim 0.3 \mu \mathrm{g} \mathrm{l^{-1 }}$ near the summer solstice, and by 2010, values of $1.5 \mu \mathrm{g} \mathrm{l}^{-1}$ were observed again (Fig. 6a).

A similar, but stronger trend to what was seen for chlorophyll was observed in the POC data (Fig. 6b). Note that all of the POC samples from 2004 were lost, causing the gap in the Hövmoller plot. Nonetheless, the POC concentration dropped from $\sim 175 \mu \mathrm{g} \mathrm{Cl}^{-1}$ to $125 \mathrm{\mu g} \mathrm{Cl}^{-1}$, a drop of $30 \%$ from 2006 to 2009, with a slight increase again in 2010. PIC showed an overall decrease in 2006, especially in the JB. The SS and WMCC waters were characterized by increased PIC concentrations in 2006.

Maximum photosynthesis $\left(\mu g \mathrm{l}^{-1} \mathrm{~d}^{-1}\right)$ showed an order-of-magnitude drop from 2006 to 2007 (Fig. 7a), with a slight resurgence of the $P_{\max }$ values at the JB-SS boundary in 2009. The same was true for chlorophyll-normalized maximum production $\left(P_{\mathrm{m}}^{\mathrm{b}}\right)$, although the relative changes were not quite as large (Fig. 7b). Of all of the rate measurements, calcification showed a clear decrease after the summer of 2007, decreasing to barely measurable values with little resurgence thereafter (Fig. 7c).

Absorption and backscattering of the dissolved and particulate material showed a step-change after 2005 on the western side of the GoM. The dissolved absorption at $412 \mathrm{~nm}, a_{\mathrm{g} 412}$ (dominated by humic materials) (Kirk 1994), was strongly enhanced in the ExtEMCC and WMCC on the western side of the Gulf (Fig. 8a). Particulate plus dissolved absorption at $440 \mathrm{~nm}\left(a_{\mathrm{gp} 440}\right)$ (Fig. 8b) showed the same trend as $a_{\mathrm{g} 440}$ but with added peaks on the eastern side of the Gulf, in SS waters. The values of $a_{\mathrm{g} 412}$ and $a_{\mathrm{gp} 412}$ in JB showed little change over the entire time series. Par- ticulate backscattering at $532 \mathrm{~nm}, b_{\mathrm{bp} 532}$, was highest in the nearshore waters after 2005 (Fig. 8c). In 3 years (2005, 2006, 2010), elevated values of $b_{\mathrm{bp} 532}$ were observed in JB waters.

Properties derived from multiple GNATS variables also are shown as Hövmoller plots (Fig. 9). For example, using the parameterization of the phytoplankton package effect (chlorophyll-specific absorption cross section; $a^{*}{ }_{440}$, with units of $\mathrm{m}^{2} \mathrm{mg} \mathrm{chl}^{-1}$ ) as a function of chlorophyll (Bricaud et al. 1998, their eq. 2'), we calculated the phytoplankton absorption at $440 \mathrm{~nm}$ $\left(a_{\phi 440}\right)$ based on measured chlorophyll. We then compared this to the measured total particulate and dissolved absorption $\left(\mathrm{a}_{\mathrm{gp} 440}\right)$. The ratio of $a_{\mathrm{gp} 440}: a_{\phi 440}$, i.e. the ratio of the total particulate and dissolved absorption to just the phytoplankton absorption at $440 \mathrm{~nm}$, was typically highest in the WMCC and Ext EMCC associated with fall freshets each year (ratios >10) (Fig. 9a). For 1 year (2002), there were elevated ratios observed in these waters for the entire year, reaching all the way to the interior of the JB. In 2005 and 2007 to 2010, there were sustained periods when the $a_{\text {gp } 440}: a_{\phi 440}$ ratio was as high as 15 in the WMCC and ExtEMCC for more than just the fall freshets.

Carbon-specific growth rates of the POC and PIC were derived by dividing the carbon fixation rates by their respective standing stocks. Note, this implicitly assumes that all POC is living, which we know is not the case (Verity et al. 2000); hence, the growth rate calculations given here are conservative. Carbonspecific growth rate estimates prior to the step decrease in photosynthesis were $\sim 0.4 \mathrm{~d}^{-1}$ across most of the GoM, except at the frontal boundary between the SS and JB waters from 2001 to 2002, where growth rates exceeded $1 \mathrm{~d}^{-1}$ (Fig. 9b). After the productivity step decline in 2007, POC-specific growth rates dropped precipitously to $<0.1 \mathrm{~d}^{-1}$ across the GoM. PIC growth rates calculated in the same fashion were always low in the SS water and $\sim 0.2$ to $0.3 \mathrm{~d}^{-1}$ for the remainder of the Gulf until late 2007 (Fig. 9c).

\section{Gulf-wide anomaly plots}

Monthly Gulf-wide anomalies showed coherent changes over time (Figs. 10 to 14). For example, the GoM SST was characterized by an anonymously cool period during September 1998 and between July 2001 and August 2005. Warmer than average conditions characterized the GNATS transect from 1999 to June 2001 and from August 2005 to the end of 2010, with brief cool intervals during June and July of 2007 


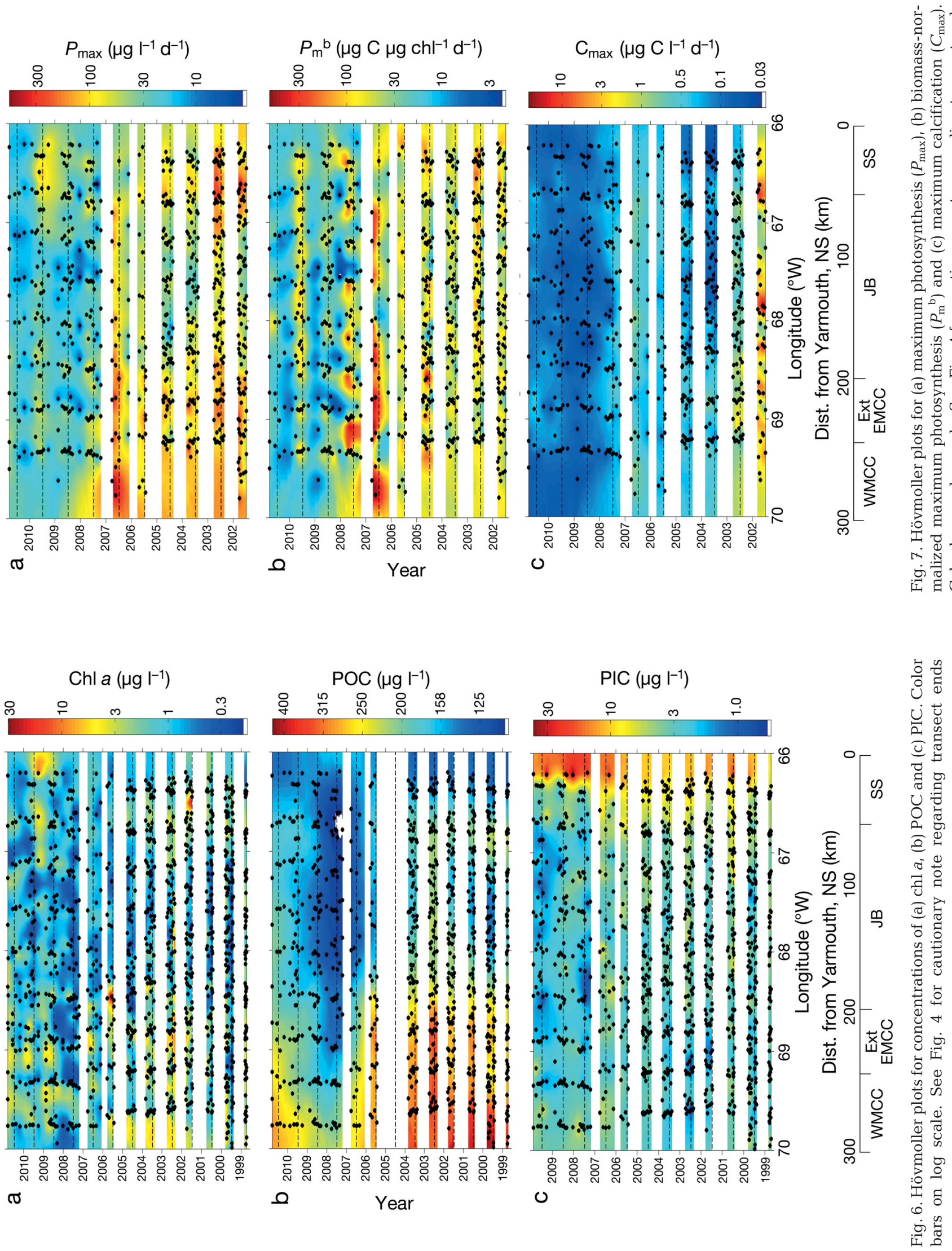




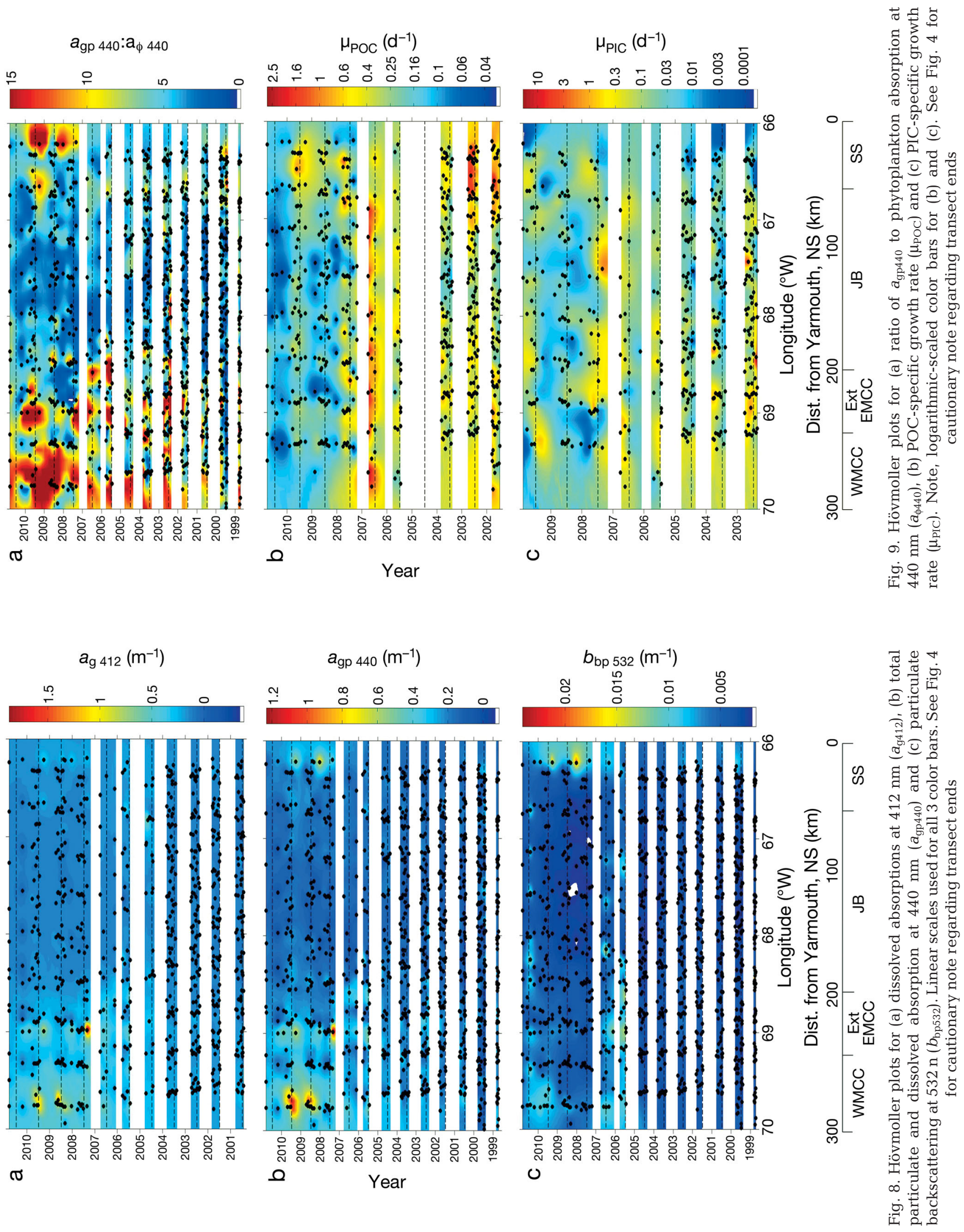



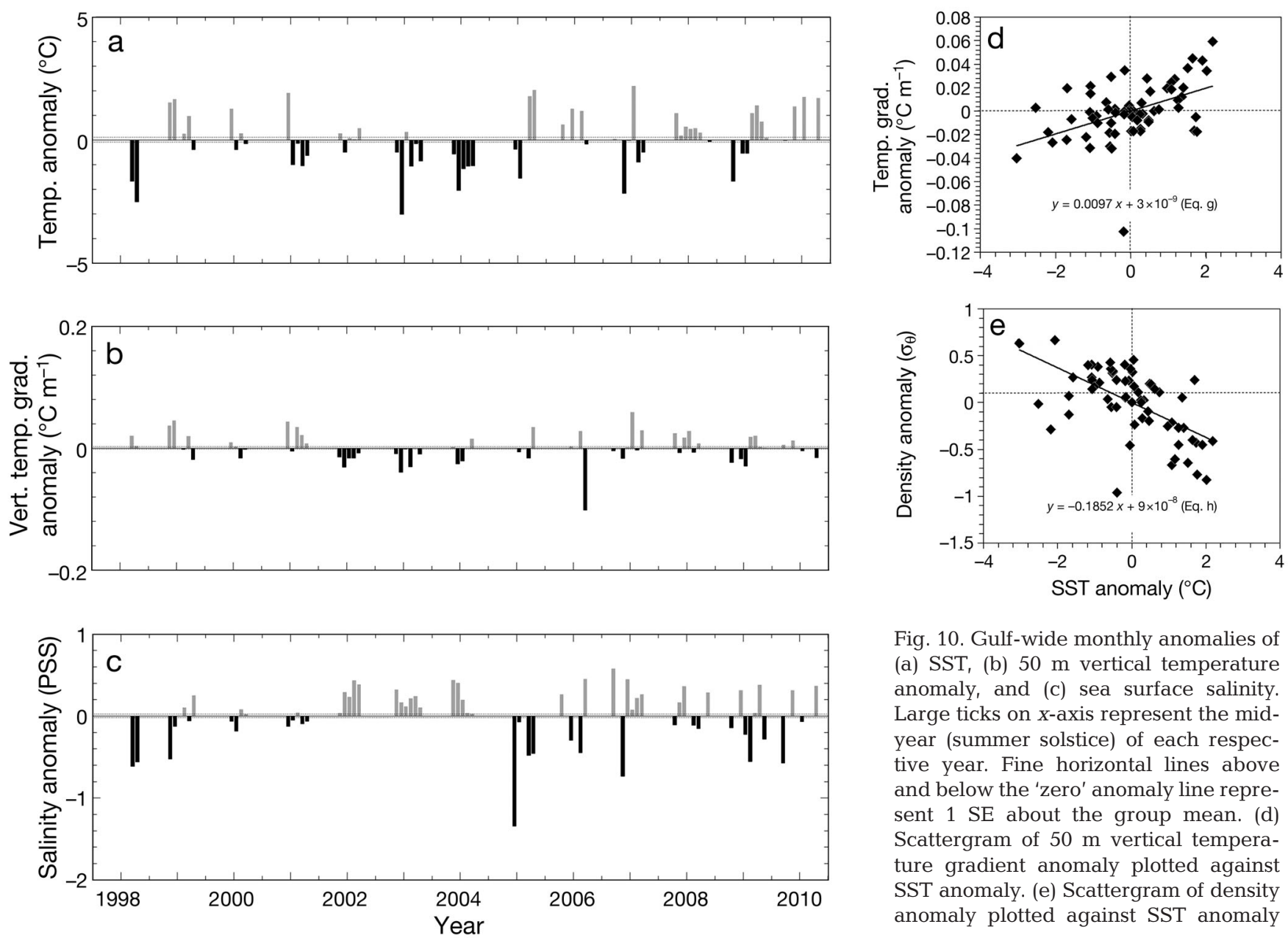

Fig. 10. Gulf-wide monthly anomalies of (a) SST, (b) $50 \mathrm{~m}$ vertical temperature anomaly, and (c) sea surface salinity. Large ticks on $x$-axis represent the midyear (summer solstice) of each respective year. Fine horizontal lines above and below the 'zero' anomaly line represent 1 SE about the group mean. (d) Scattergram of $50 \mathrm{~m}$ vertical temperature gradient anomaly plotted against SST anomaly. (e) Scattergram of density anomaly plotted against SST anomaly

and 2009 (Fig. 10a). The average vertical temperature gradient (over the top $50 \mathrm{~m}$ ) generally showed a similar, but not identical, pattern to the SST anomaly; that is, the gradient was anomalously high from 1998 to late 2002, followed by an anonymously low gradient from May 2002 to June 2004. Vertical temperature gradients thereafter were generally higher than normal until the end of 2010, with a few exceptional months with the low temperature gradients in August 2006 and April to June 2009 (Fig. 10b). Salinity anomalies were negative in 1998 and May 1999 and then were mostly positive until May 2005. Thereafter, salinity anomalies showed a higher frequency of negative values ( -0.75 to -1 PSS) (Fig. 10c). The Gulf-wide anomalies for vertical temperature gradients were significantly correlated to the SST anomalies (Fig. 10d, Table 1g). The density anomalies were significantly inversely correlated to the SST anomalies (Fig. 10e, Table 1h).

The variability observed in the nutrient anomalies (DIN, phosphate and silicate) was correlated (Fig. 11). From the start of sampling to spring 2003, the monthly Gulf-wide nutrient anomalies were generally positive. From summer 2003 to autumn 2006, the monthly anomalies for all 3 nutrients became negative. The Gulf-wide anomalies once again became positive from 2007 to 2009, after which they cycled into the negative, becoming positive again in 2010. The ratio of silicate to DIN reached 100 during 2002, when nitrate values were close to undetectable (Fig. 11d). Thereafter, the values were anomalously low. The DIN:DIP ratios covaried with the overall nutrient concentrations (Fig. 11e). That is, the DIN:DIP ratio showed anomalously negative values in 2005, when nutrients were generally low. High DIN:DIP ratios resulted when both DIN and DIP were anomalously high (compare Fig. 11e with Fig. 11a, b,c). Gulf-wide anomalies for DIN versus $\mathrm{PO}_{4}$ or DIN versus silicate showed significant correlations (Fig. 11f,g, Table 1i,j, respectively). The Gulf-wide nutrient anomalies were inversely correlated with the vertical temperature gradient, but the correlation was low, and none of the relationships were statistically significant (at $\alpha \leq 0.05$; data not shown). 

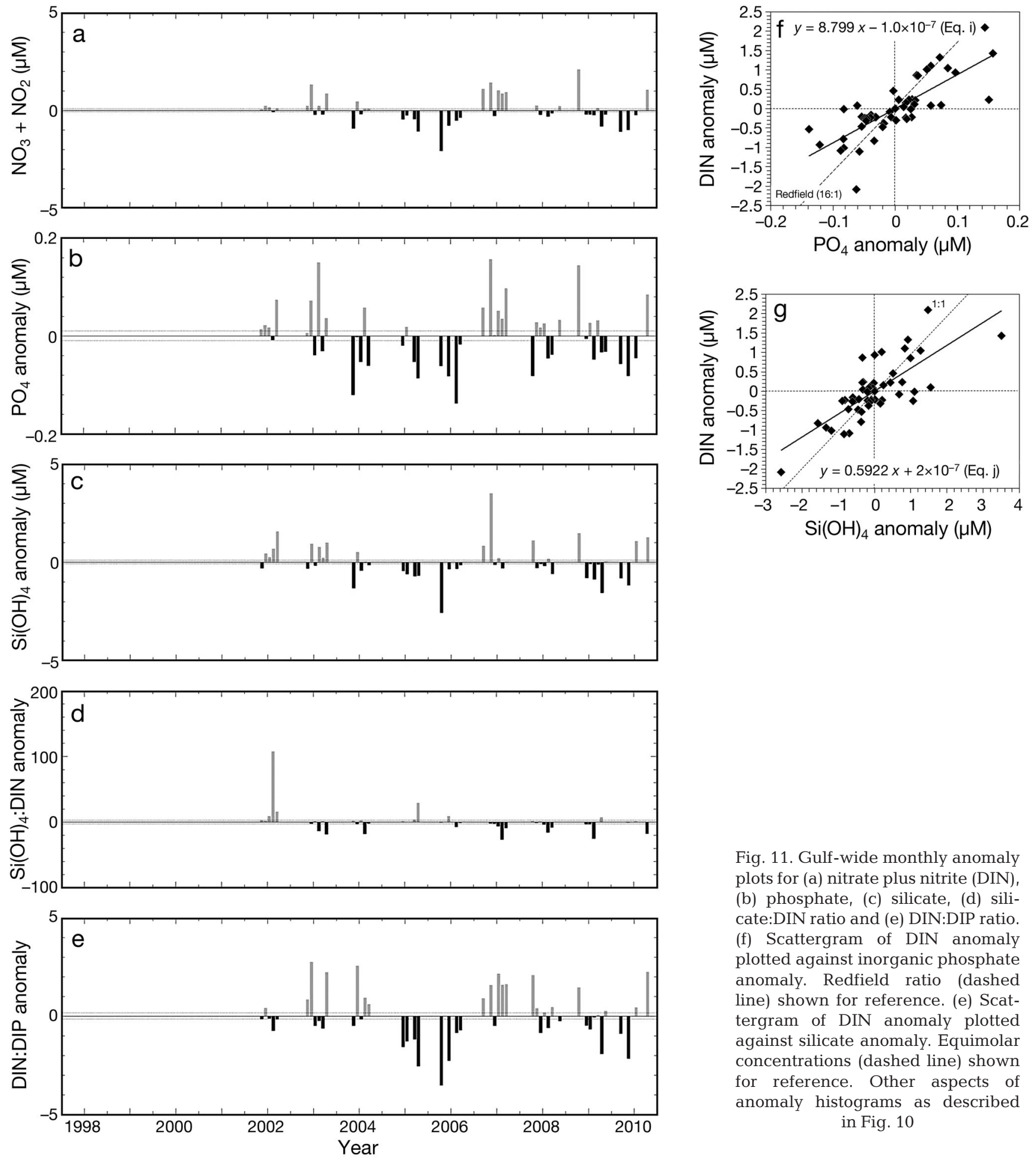

Fig. 11. Gulf-wide monthly anomaly plots for (a) nitrate plus nitrite (DIN), (b) phosphate, (c) silicate, (d) silicate:DIN ratio and (e) DIN:DIP ratio. (f) Scattergram of DIN anomaly plotted against inorganic phosphate anomaly. Redfield ratio (dashed line) shown for reference. (e) Scattergram of DIN anomaly plotted against silicate anomaly. Equimolar concentrations (dashed line) shown for reference. Other aspects of anomaly histograms as described in Fig. 10

Gulf-wide anomalies of standing stocks (POC, PON, PIC and BSi) showed considerable variability over multi-year scales (Fig. 12). For POC and PON, the anomalies were mostly positive from 1998 to 2005, after which more significant negative anomalies ensued through 2009, followed by positive anomalies during 2010 (Fig. 12a,b). PIC anomalies fluctuated between positive and negative on time scales of several months from 1998 to 2005, but negative anomalies clearly dominated from summer 2007 to the end of 2010 (Fig.12c). Biogenic silica (BSi) measurements were not started until 2004, and thus, 

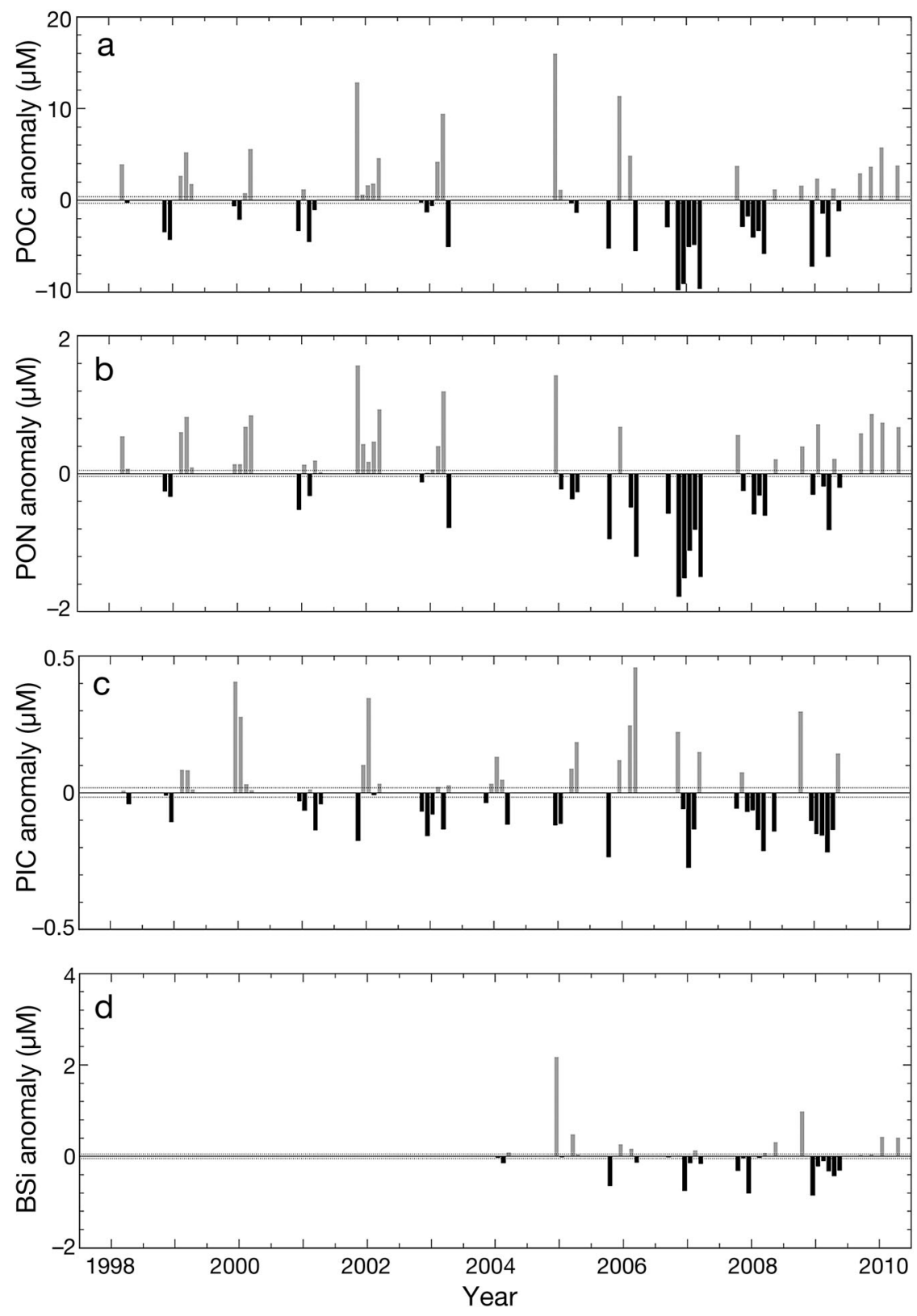
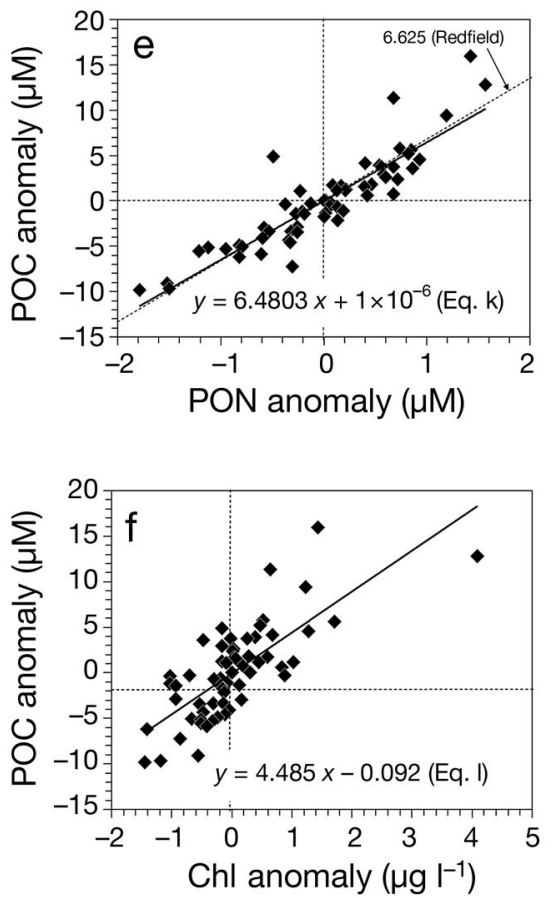

Fig. 12. Gulf-wide monthly temperature anomaly plots for (a) POC, (b) PON, (c) PIC and (d) biogenic silica (BSi). (e) Scattergram of POC anomaly plotted against PON anomaly. Redfield ratio (dashed line) shown for reference. (f) Scattergram of POC anomaly plotted against chlorophyll anomaly. Other aspects of anomaly histograms as described in Fig. 10 the record is much shorter in duration. Nonetheless, negative anomalies of BSi dominated over the same months that negative PIC anomalies were observed (Fig. 12d). It is worthy of note that the POC and PON anomalies showed significant covariance (Fig. 12e, Table 1k). Moreover, the POC anomaly also showed significant covariance with the chlorophyll anomaly (Fig. 12f, Table 11).

Anomalies of phytoplankton chlorophyll biomass (Fig. 13a) showed decreasing trends (i.e. predominantly positive anomalies to predominantly negative anomalies) over the GNATS region since 1998. Carbon fixation showed decreasing anomalies since
2001 (Fig. 13b,c). The largest positive anomaly for carbon fixation (both photosynthesis and calcification) was observed over a single month, during September 2006 (Fig. 13b,c). Primary production was significantly correlated with chlorophyll, calcification rate and POC (Fig. 13d-f, Table 1m-o).

Anomalies for CDOM absorption at $412 \mathrm{~nm}\left(a_{\mathrm{g} 412}\right)$ and dissolved plus particulate material $\left(a_{\mathrm{gp} 412}\right)$ showed a step increase in the GNATS data in late 2004, when the anomalies showed their first positive values (Fig. 14a). Since then, the anomalies of $a_{\mathrm{g} 412}$ and $a_{\mathrm{gp} 412}$ (Fig. 14b) have remained positive, with only a few exceptions. These 2 optical properties have covaried 

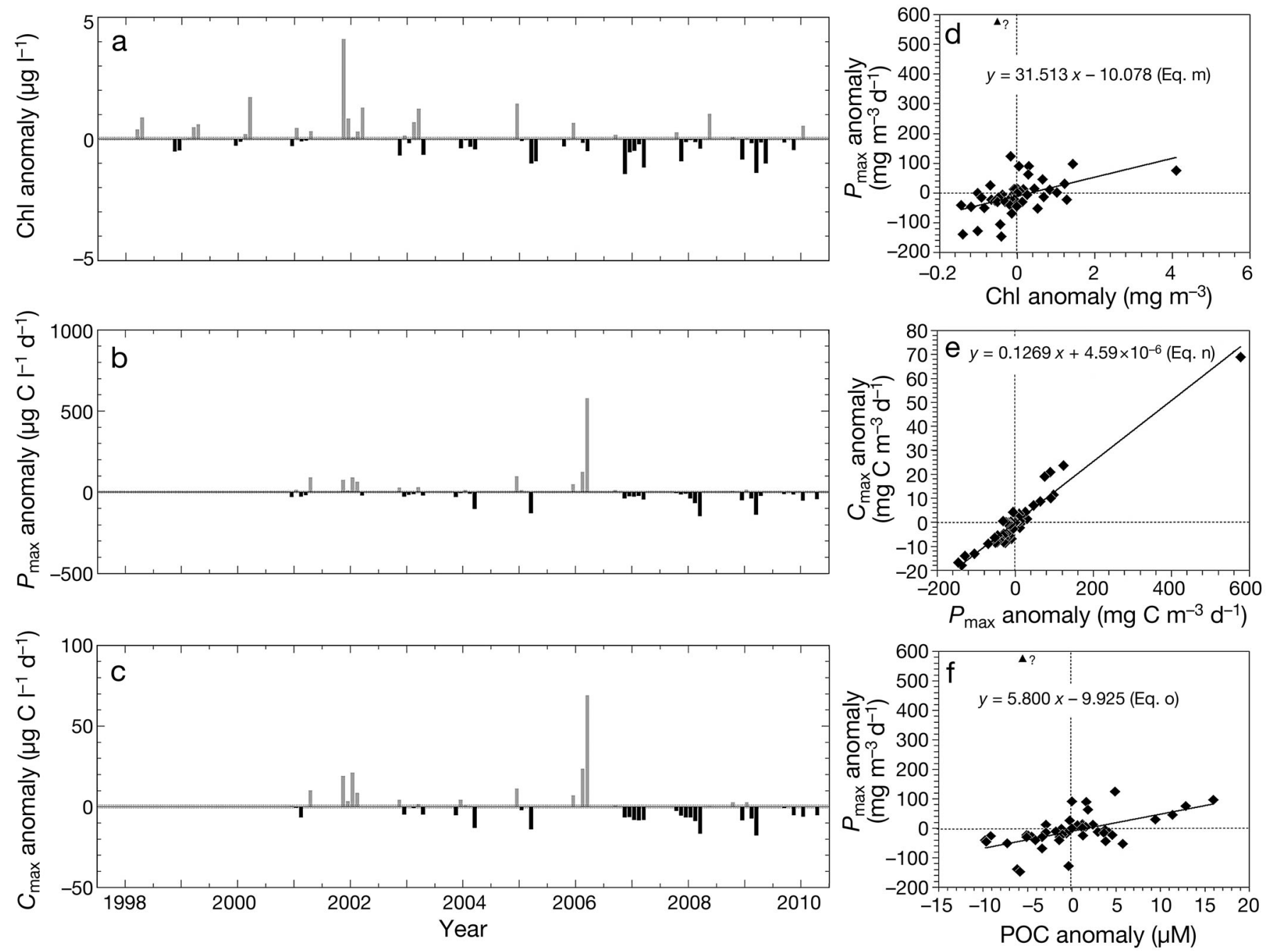

Fig. 13. Gulf-wide monthly anomaly plots for (a) chlorophyll, (b) $P_{\max }$ (c) $C_{\max }$. (d) Scattergram of $P_{\max }$ anomaly plotted against chl a anomaly. (e) Scattergram of $C_{\max }$ anomaly plotted against $P_{\max }$ anomaly. (f) Scattergram of $P_{\max }$ anomaly plotted against POC anomaly. Other aspects of anomaly histograms as described in Fig. 10. Anomalous datum marked with '?' not used in estimation of least-squares relation

with low to moderate correlation (Fig. 14e, Table 1p). CDOM absorption had a statistically significant correlation with salinity (Fig. 14f, Table 1q). The backscattering of particulate material at $532 \mathrm{~nm}$ showed predominantly negative anomalies through the fall of 2004, followed by highly positive anomalies from 2005 to 2006 (Fig. 14c). Negative anomalies prevailed from 2007 to 2008 (the same months that POC experienced consistently negative anomalies), and predominantly positive anomalies prevailed thereafter. Acid labile backscattering (due to calcium carbonate; $\left.b_{\mathrm{b}}{ }_{532}\right)$ showed, like $b_{\mathrm{bp} 532}$, predominantly negative anomalies through fall 2004, followed by zero or positive anomalies through 2008 and, since then, decreasing, negative anomalies (Fig. 14d).

\section{Relationship of GNATS variables to river discharge}

To examine the variability of GNATS variables to river discharge, Gulf-wide anomalies were averaged for the 4-mo period between June and September (the months consistently sampled throughout the GNATS series). Many of these annual average anomalies were significantly correlated to the annual average Penobscot discharge at the W. Enfield, ME, stream gauge (see location in Fig. 1). For example, Gulf-wide salinity anomalies were negatively correlated to the annual average Penobscot discharge (Fig. 15a, Table 1r). Moreover, the variance associated with each average salinity anomaly increased with greater river discharge (Fig. 15b, Table 1s). 

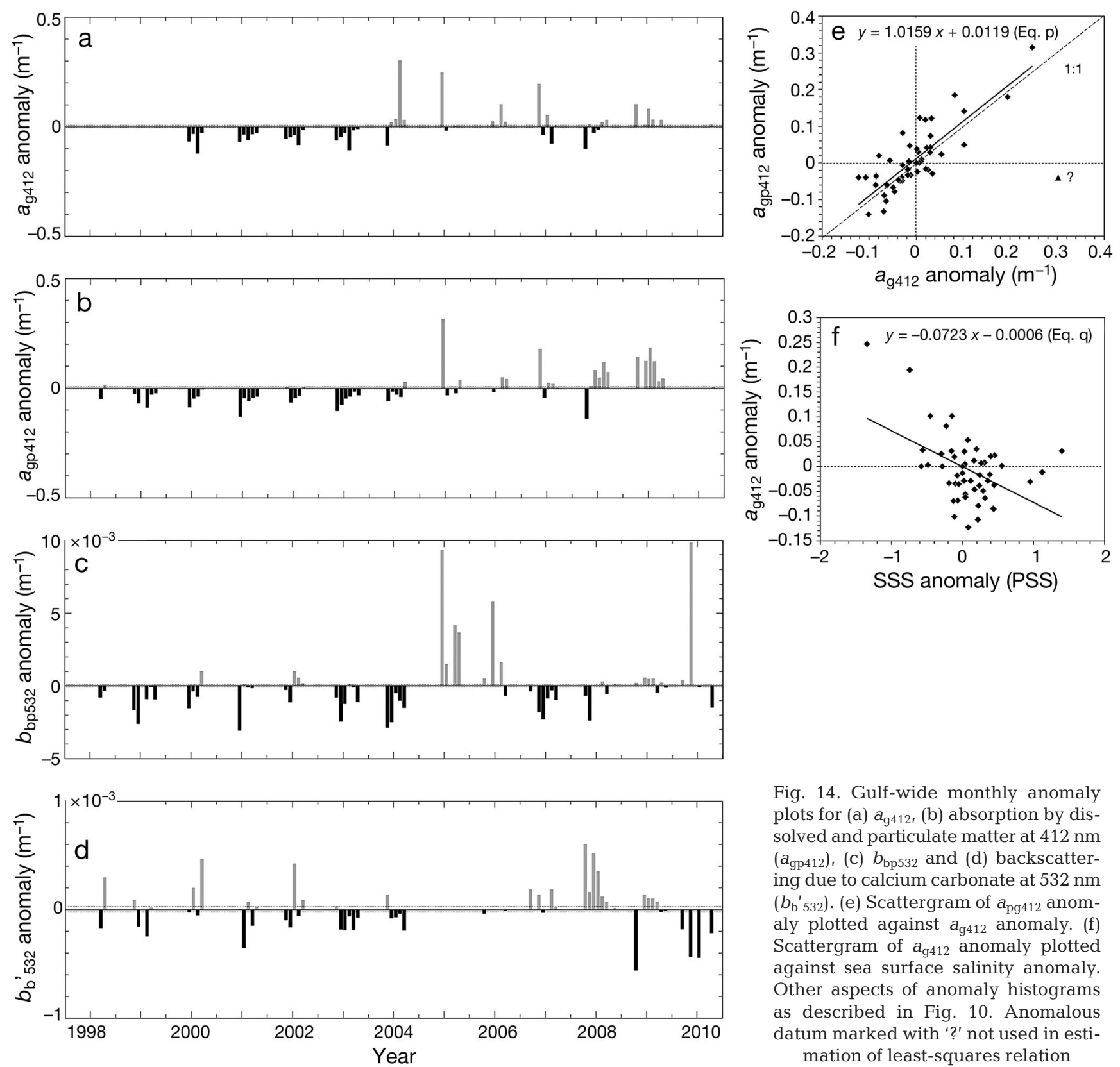

Fig. 14. Gulf-wide monthly anomaly plots for (a) $a_{9412}$, (b) absorption by dissolved and particulate matter at $412 \mathrm{~nm}$ $\left(a_{\mathrm{gp} 412}\right),(\mathrm{c}) b_{\mathrm{bp} 532}$ and (d) backscattering due to calcium carbonate at $532 \mathrm{~nm}$ $\left(b_{\mathrm{b}}{ }^{\prime}{ }_{32}\right)$. (e) Scattergram of $a_{\mathrm{pg} 412}$ anomaly plotted against $a_{\mathrm{g} 412}$ anomaly. (f) Scattergram of $a_{g 412}$ anomaly plotted against sea surface salinity anomaly. Other aspects of anomaly histograms as described in Fig. 10. Anomalous datum marked with '?' not used in estimation of least-squares relation

Similarly, Gulf-wide density anomalies decreased as river discharge increased (Fig. 15c, Table 1t). Gulfwide CDOM absorption increased with mean annual average Penobscot River discharge (Fig. 15d, Table 1u), as did Gulf-wide particle backscattering (Fig. 15e, Table 1v). Gulf-wide surface silicate concentrations showed a statistically significant decrease as river discharge increased (Fig. 15f, Table 1w). Although nitrate/nitrite and phosphate both showed negative correlations with river discharge, the relationships were not significant at $\alpha<0.05$ (data not shown).

\section{Extending GNATS from 1977 to 2010}

Data from the Yentsch \& Phinney, Boyd and MARMAP datasets were aggregated to test the null hypothesis that the changes in temperature, $50 \mathrm{~m}$ temperature gradient, salinity and chl a were not significantly different from zero. Due to geographic differences in the portions of the GNATS transect that were available from each dataset, we could only focus on data from the JB portion of the transect (which was the most common water mass sampled among the various datasets). Moreover, to 

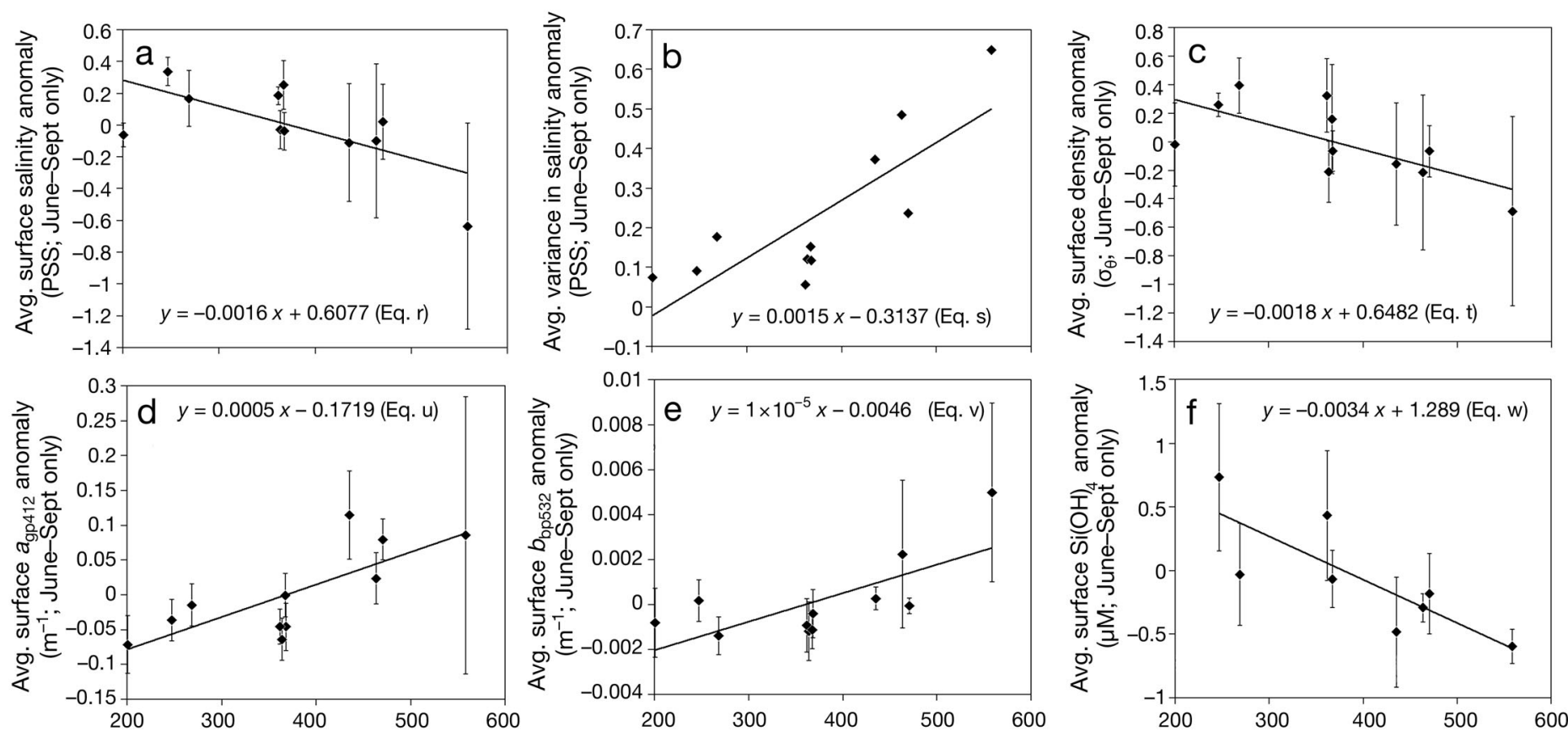

Avg. Penobscot discharge at W. Enfield $\left(\mathrm{m}^{3} \mathrm{~s}^{-1}\right)$

Fig. 15. Relationships between the annual average calendar year Penobscot River discharge (measured at W. Enfield, ME, in $\mathrm{m}^{3}$ $\mathrm{s}^{-1}$ ) and various physical, optical and chemical properties along the entire GNATS transect, between June and September. Each datum represents the Gulf-wide average anomaly for each 4-mo period. Error bars in panels a,c, d,e and f represent the standard deviation for anomalies of surface salinity (PSS), surface density ( $\sigma_{\theta}$ units), surface CDOM and detrital absorption at $412 \mathrm{~nm}$

$\left(a_{\mathrm{gp} 412} ; \mathrm{m}^{-1}\right)$, surface particle backscattering at $532 \mathrm{~nm}\left(b_{\mathrm{bp} 532} \mathrm{~m}^{-1}\right)$ and surface silicate concentration $(\mu \mathrm{M})$, respectively ensure that movement of the water mass boundaries did not bias the results, the longitude range for the analysis $\left(67.25-68.5^{\circ} \mathrm{W}\right.$ longitude) was purposefully narrowed to ensure that the JB water was always sampled within the normal range of the water mass boundaries. The net result was that by focusing on JB only, the reduced geographic variesis testing, at the expense of data from the boundary regions. In all cases, the results demonstrated that the time courses of each variable showed extremely subtle changes over time (Table 2). Over

Table 2. Results of retrospective data analysis over the last 34 yr (19772010), in which the mean rates of change were calculated and the null hypothesis was tested $\left(\mathrm{H}_{\mathrm{o}}\right.$ : rates not significantly different from zero)

\begin{tabular}{|lccc|}
\hline Variable & $\begin{array}{c}\text { Mean } \\
\text { change }\end{array}$ & $\begin{array}{c}\text { SE of } \\
\text { mean change }\end{array}$ & Probability \\
\hline Temperature $\left({ }^{\circ}{\left.\mathrm{C} \mathrm{yr}^{-1}\right)}^{\text {Temperature gradient, }}\right.$ & 0.018 & \pm 0.008 & $\mathrm{p}<0.05$ \\
$\begin{array}{c}\text { Top 50 m }\left({ }^{\circ} \mathrm{C} \mathrm{m}^{-1} \mathrm{yr}^{-1}\right) \\
\text { top }\end{array}$ & $-0.3 \times 10^{-4}$ & $\pm 4.1 \times 10^{-4}$ & $\mathrm{p}>0.05$ \\
Chlinity $\left(\mathrm{PSS} \mathrm{yr}^{-1}\right)$ & -0.0087 & \pm 0.0039 & $\mathrm{p}<0.05$ \\
& -0.015 & \pm 0.011 & $\mathrm{p}>0.05$ \\
\hline
\end{tabular}
ability increased the statistical power of the hypoth- the 1977-2010 extended database, the mean change in temperature was $0.018( \pm 0.008)^{\circ} \mathrm{C} \mathrm{yr}^{-1}$, $>2$ SE above zero $(\mathrm{p}<0.05)$. The temperature gradient in the top $50 \mathrm{~m}$, averaged over the $34 \mathrm{yr}$, showed a decrease of $-5.3 \times 10^{-4}\left( \pm 4.1 \times 10^{-4}\right)^{\circ} \mathrm{C}$ $\mathrm{m}^{-1} \mathrm{yr}^{-1}$, not statistically different from zero. Salinity showed a mean decrease of -0.0087 $( \pm 0.0039) \mathrm{PSS} \mathrm{yr}^{-1}$, which was $2 \mathrm{SE}$ different from zero $(\mathrm{p}<0.05)$. The mean trend in chlorophyll was $-0.015( \pm 0.011) \mathrm{mg} \mathrm{m}^{-3} \mathrm{yr}^{-1}$, not statistically different from zero.

\section{DISCUSSION}

\section{Century-scale climatology of the Gulf region}

Based on the 115-yr record of temperature and precipitation for the 3 weather stations around (and in) the Penobscot watershed, it is clear that there was a highly significant increase in temperature and variance in decadal precipitation patterns (see also Trombulak \& Wolfson 2004 and Keim et al. 
2003). Such results are consistent with (1) a general intensification of the hydrological cycle as the air temperature has increased (Huntington 2010) and (2) the Clausius-Clapeyron equation (which predicts that saturation water vapor pressure will increase as a function of temperature, but in this case, at a slower rate than an exponential increase) (Huntington 2010). Predictions of the magnitude of the precipitation increase range from $6 \% \mathrm{~K}^{-1}$ at $300 \mathrm{~K}$ (the tropics) and $15 \% \mathrm{~K}^{-1}$ at $200 \mathrm{~K}$ (the poles) (Moller 1963). Other estimates have averaged closer to $7 \% \mathrm{~K}^{-1}$ (Held \& Soden 2000, Huntington 2010).

Results from the 3 weather stations examined here have shown an annual temperature increase of $1.14 \times$ $10^{-2} \mathrm{~K}$ (aggregate mean for all 3 weather stations). Note, this is $65 \%$ greater than the global mean atmospheric warming rate of $0.0069 \pm 0.0017 \mathrm{~K} \mathrm{yr}^{-1}$ (Trenberth et al. 2007). We also observed an increase in the variance of precipitation of $1.1 \times 10^{-3} \mathrm{~m} \mathrm{yr}^{-1}$ and a mean annual precipitation of $1.18( \pm 0.23) \mathrm{m}$ $\mathrm{yr}^{-1}$. This equates to a rate of increase in the variability of precipitation of $\left(1.1 \times 10^{-3} / 1.18\right) / 1.14 \times 10^{-2}=$ $8.2 \% \mathrm{~K}^{-1}$, remarkably close to the above-predicted estimates (Moller 1963, Held \& Soden 2000, Huntington 2010). Given the highly significant relationship between precipitation and river discharge (Fig. 3d), the increases in precipitation likely induced increases in river discharge into the GoM, which may have influenced the step-changes in the hydrographic, biological, optical and chemical properties after 2005.

\section{Connection of river discharge to GoM-wide hydrographic and optical properties}

Evidence from the Hövmoller plots suggests a connection between the terrestrial runoff and various properties, such as salinity, density and CDOM absorption, particularly (1) on the western side of the Gulf and (2) post-2005 following the onset of extreme events. A Gulf-wide comparison, however, demonstrated that river discharge effects could be statistically detected across the entire GNATS transect, not just on the western side of the GoM, where the major rivers empty into the Gulf. Over the full range of Penobscot discharge rates, the salinity anomaly (averaged spatially across the Gulf and temporally from June to September of each year), decreased $\sim 1$ PSS, while the surface density decreased $\sim 0.6 \quad \sigma_{\theta}$ unit $\left(\mathrm{kg} \mathrm{m}^{-3}\right)$ (Fig. 15). Our interpretation of this trend is that it was not just the Penobscot River that produced this effect but the discharge from all 25 watersheds that empty into the GoM, likely subjected to similar precipitation patterns. Increased variance of the Gulf-wide salinity anomalies at high river discharge would be expected if the river discharge was concentrated in short, intense storm events (such as large spring and fall freshets; Fig. 3c). Moreover, increased CDOM and detritus absorption would be expected in the GoM associated with such extreme runoff events.

\section{Implications of a step-change in physics, chemistry and biology in the GoM}

Given the magnitude of the observed stepchange, we scrutinized the results carefully to ensure that the changes were not associated with some artifact of sampling (e.g. particular ship platform, specific sample variable, method of sampling [continuous or discrete samples]). We could find no evidence of such an artifact. Indeed, changes in hydrography of the Gulf of Maine were seen in both continuous flow-through measurements (SST and sea surface salinity [SSS]) and in situ measurements (vertical temperature gradient measured with XBT and the MVP200 profiler). Since 2005, 5 different ship platforms were used to gather these continuous and discrete data. Observations of the step-change spanned multiple variables (3 nutrients, POC, PON, primary productivity, calcification, chlorophyll and CDOM absorption).

The combination of cooler and saltier surface water resulted in a clear increase in density in the mid-Gulf after 2005 (Fig. 4d). This, combined with the elevated nutrient concentrations beginning in 2007, suggests a general deepening of the surface mixed layer. It is equally noteworthy that little change in nutrients was observed in the SS water mass (Fig. 5). Because these waters are generally entering the GoM (Brooks 1985, Xue et al. 2000), then one conclusion is that the stepchange observed in the Gulf was likely not associated with a surface advective phenomenon, such as incoming surface SS water being more nutrient rich. Instead, it was more likely associated with a change in the mixing of deeper water to the surface within the GoM. We cannot negate possible advective influence at depth, however, such as deep intrusions through the Northeast Channel supplying more nutrients (Ramp et al. 1985) that are subsequently mixed upwards into surface waters.

Intense precipitation years $(2005,2006,2008$ and 2009) were associated with reduced salinities and densities in the WMCC (with salinities dropping as low as 27 PSS). There also were drops in salinity in 
the ExtEMCC beginning in 2005 and continuing up to 2010). We interpret the reduced salinities and densities of the WMCC and ExtEMCC as resulting from increased river runoff from the surrounding watersheds of the GoM (Fig. 1), further demonstrated by the significant inverse correlation between salinity and density anomalies versus river discharge (Fig. 15). This was also evident given that the WMCC and ExtEMCC waters had reduced surface densities and elevated $50-\mathrm{m}$ temperature gradients (the land runoff was warmer than the typical WMCC and ExtEMCC waters) (Fig. 3b,d).

Anomaly plots for the hydrography and nutrients also provided insights on the step-change. The monthly anomaly plots (Fig. 11) averaged all changes across the entire GNATS transect into one Gulf-wide number. Covariance in the SST and vertical temperature gradient data (Fig. 10d) again suggested that the surface changes were representative of deeper changes occurring to $50 \mathrm{~m}$ in the water column (i.e. colder SSTs were associated with lower gradients in temperature over the top $50 \mathrm{~m}$ ) (Figs. 4a,b, 10d; see also Balch (2004), their Fig. 9 showing a significant relationship between the $50-\mathrm{m}$ temperature gradient and surface water density). Interestingly, salinity anomalies showed no statistically significant relationships to SST, vertical temperature gradients or surface density. SST accounted for most of the variance in density (Fig. 10e).

Gulf-wide anomalies for phosphate were poorly correlated to surface density anomalies $\left(\mathrm{r}^{2}=0.13\right.$; $\mathrm{p}<0.02$; data not shown) and not significantly correlated to vertical temperature gradients. Nitrate anomalies were only barely correlated to surface density $(p<0.1)$. Townsend et al. (2010) showed for a 54-yr dataset of stations within the Gulf of Maine (in the geographic box $42.3-43.61^{\circ} \mathrm{N}, 68.6-66.1^{\circ} \mathrm{W}$ and at $100 \mathrm{~m}$ depth) that since 1998 , the temperature and salinity anomalies have been decreasing from anomalously positive to average. Thomas et al. (2003) showed, using satellite data, that 1998 was an anomalously cold year associated with the minimum of the North Atlantic Oscillation (NAO; 5-mo running mean). This is consistent with the GNATS data, in which salinity anomalies were uniformly positive from 2002 to 2004 and decreased thereafter. The trends of our SST data differ from the $100 \mathrm{~m}$ depth values of Townsend et al. (2010), however, in that GNATS SST values were uniformly negative from 2002 to 2004 and more positive thereafter.

The biological response to the step-change in physics and chemistry (increased temperature, de- creased salinity and increased nutrients) was harder to interpret and admittedly counterintuitive because the response to increased nutrients in 2007 was a step decrease in productivity (as $P_{\max }$ and $C_{\max }$ ) and phytoplankton biomass (as chlorophyll and POC). Primary production showed the largest decline in the $\mathrm{JB}$, ExtEMCC and WMCC waters, precisely where the biggest increase in nutrients was observed. One possible explanation was that deeper mixing meant that populations were more light-limited. The problem with this interpretation is that the productivity incubations were done in bottles kept at ambient surface light intensities and day:night photocycle from the moment that the water was collected to the beginning of the ${ }^{14} \mathrm{C}$ incubations $(2$ to $18 \mathrm{~h}$ ). Thus, over this time period, the phytoplankton should have begun to adapt to light. Indeed, deep, low-lightadapted populations, when mixed into surface waters and kept at high light and nutrient conditions, show an up-shifted physiological response over the course of $2 \mathrm{~d}$ (Dugdale et al. 1989). While such a shiftup response would have been observed throughout all of the GNATS sampling, with the deeper mixing commencing in 2007, the magnitude of the shift-up response should have increased after this date. The bigger problem is that the shift-up hypothesis does not predict a decrease in surface $P_{\max }$ associated with the deeper mixing and higher nutrients. Could the step decrease in primary production have somehow been associated with the extreme precipitation and river discharge events after 2005 ?

\section{River discharge and its potential effects on primary production}

We examined whether the dramatic step-decrease in carbon fixation was consistent with an inhibitory effect of something introduced into the GoM, associated with the extreme river discharge (such as xenobiotics). Such a hypothesis would be most plausible in the ExtEMCC and WMCC, where surface salinities were observed to decrease from 32 to 27 PSS (representing a relative dilution of surface waters by $\sim 16 \%$ ). However, there was no correlation between the anomalies of salinity and carbon fixation (whether primary production or calcification), negating this hypothesis. Further, carbon fixation showed no relationship with river discharge.

However, absorption of CDOM overlaps with chlorophyll absorption and, in effect, would have competed with chl a absorption (Fig. 9a). These observations clearly suggested that in the western 
coastal GoM, both CDOM and detritus could have been a significant competitor for light absorption in the Soret band of chlorophyll. Indeed, CDOM absorption dominated over detrital absorption, as evidenced by the 1:1 slope (Fig. 14e), indicating that most of the variability in $a_{\text {pg } 412}$ was due to variation in $a_{\mathrm{g} 412}$. There was also almost a doubling in the particulate backscattering at $532 \mathrm{~nm}$ in 2005, 2006 and 2010, particularly in the WMCC and ExtEMCC (Fig. 8c), suggestive of periods when inputs of riverborn particulate matter were reaching well into the western GoM. This is consistent with previous observations of the strong Case II characteristics of the GoM for CDOM, punctuated by periods when waters were Case II particulate (Balch et al. 2004).

The importance of the GoM watersheds for supplying highly absorbing CDOM and optically backscattering particles (both of which would reduce light penetration into the surface ocean) was further buttressed by the statistically significant positive correlation of these variables with the annual average Penobscot River discharge (Fig. 15d,e). The scale of the Gulf-wide change was large, with an increase in CDOM and detrital absorption of $0.2 \mathrm{~m}^{-1}$, over the full range in river discharge. Increases in particulate backscattering could have been associated with suspended sediments supplied from rivers but could also have been associated with flocculation processes (George et al. 2007) as the concentrated DOM of rivers met seawater.

While there was no step increase in the $a_{\mathrm{gp} 440}: a_{\phi 440}$ ratio that exactly mirrored the step drop in $P_{\max }$ across the entire GoM, it is apparent that following 2005 , the $a_{\mathrm{gp} 440}: a_{\phi 440}$ ratio reached new highs in the western GoM, with a few extremely high values even seen in the eastern GoM, never before seen in the GNATS record. Taken together, these results suggest an extraordinary input of CDOM and detritus from the GoM watersheds along with potential light-limitation of phytoplankton primary production after 2005 in the WMCC and ExtEMCC and, for the first time, in the SS water. Without parallel photosynthesis versus irradiance data, plus light extinction data over the water column, it will be difficult to verify this unequivocally. The source of the CDOM on the east side of the GoM is not known, but likely CDOM was advected into the GoM from waters originating in the eastern shore of Nova Scotia and perhaps, ultimately, the Saint Lawrence estuary (Smith et al. 2001). The fact that CDOM absorption increased Gulf-wide, in response to increased river discharge (Fig. 15d), suggests that it could have had impacts in the JB as well.

\section{Impact of the decrease in primary production and calcification}

Quite apart from the reasons for the productivity decrease in the GoM following 2007, questions about the impact of the decline in photosynthesis and calcification on carbon-specific growth rates are worthy of discussion as they allow more insight into the scale of the problem for carbon cycling in this shelf sea. POCspecific growth rates of 1 to $2 \mathrm{~d}^{-1}$ were common from 2002 (when measurements were started) to 2006 and are close to maximal values seen in cultures that are characteristic of high export regions, such as the Arabian Sea and other upwelling areas (Banse 1988). Values below $0.1 \mathrm{~d}^{-1}$ represent extremely slow-growing populations, often seen in oligotrophic regions such as the subtropical North Pacific Central Gyre (Eppley 1972) (but with some noted exceptions; see Laws et al. 1984). While we did not sample variables associated with higher trophic levels, it is unlikely that such a decrease in productivity at the base of the marine food web could have anything other than a negative impact on the higher trophic levels in the GoM.

The results of the carbon-specific growth rate of PIC (Fig. 9c) were consistent with what is known about the distribution of coccolithophores in the GoM, where diatoms are favored in SS water, and blooms begin at the JB/SS frontal boundary and grow inwards into the GoM (Balch 2004). In 2008 and early 2009, however, the PIC-specific growth rates were essentially unmeasurable across the entire GoM, unprecedented within the GNATS record. The slight rebound in PIC-specific growth rate in 2010 (Fig. 9c) suggests that coccolithophore growth was returning more to the pre-2007 levels. The mechanism for this is not obvious because $E$. huxleyi (the numerically abundant coccolithophore species in the GoM) (Balch et al. 1991) prefers moderately stratified environments (Balch 2004), and we demonstrated earlier that there was evidence for more mixing from 2006 to 2010, based on the 50-m temperature gradients (Fig. 4b).

\section{Long-term changes along the GNATS transect}

From the long-term perspective, changes in temperature, vertical temperature gradients (top $50 \mathrm{~m}$ ), salinity and chlorophyll were difficult to discern within the natural noise of the data, and only certain changes were statistically significant at $\alpha<0.05$. Changes in the nutrients have been tied to the influence of warm, salty NASW or cold and fresher LSW, which, in turn, have been tied to the North Atlantic 
Oscillation (Pershing et al. 2001, Smith et al. 2001). Our results for the 34-yr record confirm the influence of fresher water in the late 1990s, associated with the dip in the NAO index from the same period (Smith et al. 2001, Townsend et al. 2010). However, attempts to correlate the monthly GNATS hydrographic data to the monthly-binned NAO index showed no significant correlations, at least on a Gulf-wide basis.

The net trends that we observed from the 1970s to the present, however, did show a significant, albeit small, decrease in salinity and increase in SST (Table 2), consistent with the data of others (Townsend et al. 2010). The net increase in GoM SST of $0.018 \pm 0.008^{\circ} \mathrm{C}^{-1} \mathrm{r}^{-1}$ (Table 2) qualified as a moderate warming rate, virtually identical to the global mean SST warming rate estimated by Belkin (2009) (0.0177 $\pm 0.0052^{\circ} \mathrm{C} \mathrm{yr}^{-1}$ between 1981 and 2005; see his Fig. 3) and slightly greater than the global SST warming rate cited by Trenberth et al. $(0.0133 \pm$ $0.0047^{\circ} \mathrm{C} \mathrm{y}^{-1}$ between 1979 and 2005; see their Table 3.2). Moreover, our observed salinity changes can be compared to other studies. For example, the salinity of the subpolar north Atlantic basin at $45^{\circ} \mathrm{N}$ latitude has been decreasing at a rate of about -0.001 PSS $\mathrm{yr}^{-1}$ between 1955 and 1998 (Bindoff et al. 2007). This is considerably less than the salinity decrease observed in the GoM, however $(-0.0087 \pm 0.0039$ PSS $\mathrm{yr}^{-1}$ between 1975 and 2010) (Table 2). The greater freshening rate in the coastal GoM compared to the oceanic north Atlantic is likely due to the proximity of the multiple freshwater sources in the GoM.

The changes in the nutrient field were a function of the temporal and spatial scales over which they were examined. For example, in the nutrient Hövmoller plots (Fig. 5; which show contours based on averaging over space/time scales of $8 \mathrm{~km}$ and $14 \mathrm{~d}$, respectively), within the $\mathrm{JB}$, ExtEMCC and WMCC water masses, the silicate, DIN and DIP concentrations increased $\sim 3$-fold after the stepchange, as the vertical temperature gradients decreased. In contrast, silicate anomalies (averaged over the space/time scales of the entire GNATS transect [300 km] and 4-mo time periods, respectively) were significantly inversely correlated with the annual river discharge (Fig. 15f). That is, over these larger spatial and temporal scales, freshwater discharge was somehow reducing nutri- ent concentrations, and river contributions of silicate were not significant to the overall budget.

The importance of silicate-rich water originating in the deep LSW, and subsequently mixed upwards, however, was seen in the ratio of silicate to DIN, which was formerly elevated only in SS water but from 2007 to 2008 was elevated all the way across the GoM, in a step-wise fashion (Fig. 16). The surface SS water on the east side of the GoM showed little change in DIN, phosphate or silicate concentrations from 2003 to 2010 (Fig. 5), and there was certainly no step-change in 2005, hence the source of the elevated nutrients in the GoM was not surface SS water entering the GoM.

Our observations, taken together with those of Townsend et al. (2010), indeed suggest that deep waters could be the ultimate source of increased nutrients after 2005 as the deep waters were mixed to the surface through seasonal cycles of deep convective mixing. The extreme precipitation events after 2005, however, allowed significant amounts of CDOM to be mixed into the GoM, thus competing with chlorophyll-containing phytoplankton for light absorption, resulting in decreased primary production and reduced nutrient draw-down.

\section{Concluding remarks}

These observations suggest that physical, optical and biological step-changes in the GoM appear to be

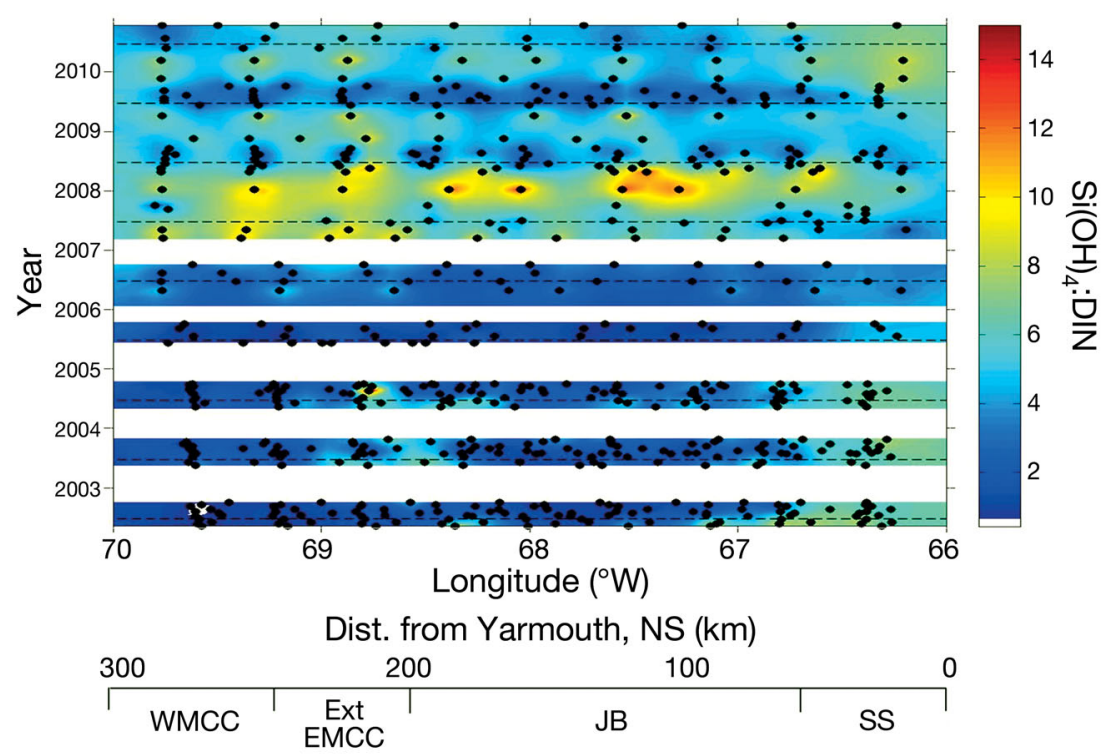

Fig. 16. Hövmoller plot for ratio of dissolved silicate to DIN. Linear colorscale bar shown to right. The kriged results near ends of the transect should be interpreted with caution due to reduced data coverage 
less related to the surface SS waters entering the Gulf and more related to (1) significant precipitationdriven fluxes of terrestrially derived material from the GoM watersheds (which supply both highly absorbing and highly scattering materials) and (2) changes in the vertical mixing of deep water (the source of which enters through the Northeast Channel). The ultimate cause of this enhanced vertical mixing is not apparent because other climatological forcings (e.g. wind data) were not included in this analysis.

The connection between freshwater river discharge and the influx of deep water entering through the Northeast Channel was suggested earlier (Hopkins \& Garfield 1979, Brooks 1992). They described an inverse relation between freshwater inflow into the GoM and the inward flux of deep slope water through the Northeast Channel (Fig. 1). An accumulation of fresh river water within the GoM (at the average rate of $3000 \mathrm{~m}^{3} \mathrm{~s}^{-1}$ or $95 \mathrm{~km}^{3} \mathrm{yr}^{-1}$ ) (Meade \& Emery 1971) promotes a barotropic pressure head that inhibits the inflow of deep slope water. They further hypothesized that during wet years, the influx of deep slope water (with its associated nutrients) would be delayed, thus lowering overall productivity the following year. This is consistent with the negative correlation between the averaged annual, Gulfwide, nutrients and river discharge (e.g. Fig. 15f). We would add that extended periods of extreme precipitation, such as those since 2005, along with inhibiting deep intrusions of slope water and associated nutrients, would also tend to stabilize the water column and support massive riverine discharges of CDOM and detritus (detectable Gulf-wide) (Fig. 15d), and these inputs likely decreased primary productivity via light limitation. The reduced productivity then resulted in lower nutrient drawdown (hence higher concentrations). Thus, in this coastal regime, the decrease in productivity did not appear to be due to only warming of the surface ocean (Behrenfeld et al. 2006) but to a complex interplay among extreme precipitation events and their associated effects on river discharge and injections of highly absorbing cDOM into the GoM. These changes were superimposed on broader-scale hydrographic effects associated with the warming and freshening of surface waters as well as deep nutrient injections into the GoM.

All of these changes are ultimately driven by changes in the North American hydrological cycle (evaporation/precipitation), warming and melting of the polar ice cap (which will reduce salinities in the southward-flowing Labrador Current). The striking aspect of the GNATS observations is the sheer mag- nitude and rapidity with which these changes occurred. This will make prediction of future change inherently more difficult in this complex shelf sea. The challenge for future prediction of the impact of climate change on the physics, chemistry, optics and biology of the Gulf of Maine will be to further integrate the modeling over these multiple domains and to define their complex interactions.

Acknowledgements. Assistance in the collection of these data was provided over the years by D. Alley, E. Booth, S. Komoroski, L. Lubelczyk, C. Rauschenburg (Bigelow Laboratory for Ocean Sciences), E. Lyczskowski and A. Ashe (University of Maine Orono), E. Olson (MIT/WHOI Joint Program), L. Windecker (University of California Santa Barbara) and J. Goes (Lamont-Doherty Earth Observatory). We gratefully acknowledge the owners, captains, crews and staff of the MS 'Scotia Prince' (Scotia Prince Cruises), FV 'Ella \& Sadie' (Samoset Seafood), RV 'Argo Maine' (Downeast Marine Resources), RV 'Connecticut' (Univ. Connecticut) and MV 'The CAT' (Bay Ferries) for accommodating the GNATS program for $12 \mathrm{yr}$. The climatological data were amassed and made available by M. J. Menne, C. N. Williams, Jr., and R. S. Vose (National Climatic Data Center, NOAA, Asheville, NC). The map in Fig. 1 was based on an earlier version by Richard D. Kelly, Jr., Main State Planning Office, created for the Gulf of Maine Council on the Marine Environment. Any use of trade, product, or firm names is for descriptive purposes only and does not imply endorsement by the US Government. Primary funding for GNATS since the beginning has been generously provided to W.M.B. by NASA (grants NAS5-97268; NAS5-31363; NAG5-10622; NNG04Gl11G; NNG04HZ25C; NNX07AD01G; NASA EPSCOR EP-02-14; NNX08AB10G; NNX08AJ88A; NNX10AT67G). Additional support was generously provided by NOAA (40AA-NE-005996), NSF (OCE-0136541; OCE-0325937; OCE0322074 subgrant S0793A-D; OCE-0728582; OCE-0961660) and ONR (N00014-98-1-0882; N00014-01-1-0042; N0001405-1-0111) to W.M.B. The comments of 4 anonymous reviewers and B. Butman (US Geological Survey, Woods Hole, MA) on an earlier version of the manuscript are much appreciated and greatly improved it.

\section{LITERATURE CITED}

Balch WM (2004) Re-evaluation of the physiological ecology of coccolithophores. In: Thierstein HR, Young JR (eds) Coccolithophores: from molecular processes to global impact. Springer-Verlag, New York, NY, p 165-190

Balch WM, Holligan PM, Ackleson SG, Voss KJ (1991) Biological and optical properties of mesoscale coccolithophore blooms in the Gulf of Maine. Limnol Oceanogr 36: 629-643

Balch WM, Drapeau DT, Bowler BC, Booth ES, Goes JI, Ashe A, Frye JM (2004) A multi-year record of hydrographic and bio-optical properties in the Gulf of Maine: I. Spatial and temporal variability. Prog Oceanogr 63:57-98

Balch WM, Drapeau DT, Bowler BC, Booth ES, Windecker LA, Ashe A (2008) Space-time variability of carbon standing stocks and fixation rates in the Gulf of Maine, along the GNATS transect between Portland, ME, and Yarmouth, NS. J Plankton Res 30:119-139 
Banse K (1988) Estimates of average phytoplankton division rates in the open Arabian Sea. Indian J Mar Sci 17:31-36

- Behrenfeld MJ, O'Malley RT, Siegel DA, McClain CR and others (2006) Climate-driven trends in contemporary ocean productivity. Nature 444:752-755

Belkin IM (2009) Rapid warming of large marine ecosystems. Prog Oceanogr 81:207-213

Bindoff NL, Willebrand J, Artale V, Cazenave A and others (2007) Observations: oceanic climate change and sea level. In: Solomon S, Qin D, Manning M, Chen Z and others (eds) Climate Change 2007: The physical science basis. Contribution of Working Group I to the Fourth Assessment Report of the Intergovernmental Panel on Climate Change. Cambridge University Press, Cambridge, UK, and New York, NY, p 385-432

Bisagni JJ, Gifford DJ, Ruhsam CM (1996) The spatial and temporal distribution of the Maine Coastal Current during 1982. Cont Shelf Res 16:1-24

Boyd CM (1985) Is secondary production in the Gulf of Maine limited by the availability of food? Arch Hydrobiol (Beih.) 21:57-65

> Bricaud A, Morel A, Babin M, Allali K, Claustre H (1998) Variations of light absorption by suspended particles with the chlorophyll a concentration in oceanic (case 1) waters: analysis and implications for bio-optical models. J Geophys Res 103:31033-31044

Brooks D (1985) Vernal circulation in the Gulf of Maine. J Geophys Res 90:4687-4705

Brooks DA (1992) A brief overview of the physical oceanography of the Gulf of Maine. In: Wiggin J, Mooers CNK (eds) Gulf of Maine scientific workshop. Gulf of Maine Council on the Marine Environment, Urban Harbors Institute, University of Massachusetts, Boston, Woods Hole, MA, p 51-74

Brooks DA, Townsend D (1989) Variability of the coastal current and nutrient pathways in the Gulf of Maine. J Mar Res 47:303-321

Campbell JW, O'Reilly JE (1988) Role of satellites in estimating primary productivity on the northwest Atlantic continental shelf. Cont Shelf Res 8:179-204

Cember RP, Wilks DS (1993) Climatological atlas of snowfall and snow depth for the northeastern United States and southeastern Canada. Report No. No. RR 93-1, Northeast Regional Climate Center, Ithaca, NY

Collins MJ (2009) Evidence for changing flood risk in New England since the late 20th century. J Am Water Resour Assoc 45:279-290

> Cronan CS, Piampiano JT, Patterson HH (1999) Influence of land use and hydrology on exports of carbon and nitrogen in a Maine river basin. J Environ Qual 28:953-961

Denman KL, Brasseur G, Chidthaisong A, Ciais P and 11 others (2007) Couplings between changes in the climate system and biogeochemistry. In: Solomon S, Qin D, Manning $M$, Chen Z and others (eds) Climate change 2007: The physical science basis. Contribution of Working Group I to the Fourth Assessment Report of the Intergovernmental Panel on Climate Change. Cambridge University Press, Cambridge, UK, and New York, NY, p 499-587

Dugdale RC, Morel A, Bricaud A (1989) Modeling new production in upwelling centers: a case study of modeling new production from remotely sensed temperature and color. J Geophys Res 94:18119-18132

Eppley RW (1972) Temperature and phytoplankton growth in the sea. Fish Bull 70:1063-1085
George DA, Hill PS, Milligan TG (2007) Flocculation, heavy metals $(\mathrm{Cu}, \mathrm{Pb}, \mathrm{Zn})$ and the sand-mud transition on the Adriatic continental shelf, Italy. Cont Shelf Res 27: 475-488

Griffith DM, Alerich CL (1996) Forest statistics for Maine, 1995, Vol 135. USDA Forest Service, Radnor, PA

> Groisman PY, Knight RW (2008) Prolonged dry episodes over the conterminous United States: new tendencies emerging during the last 40 years. J Clim 21:1850-1862

> Hayhoe K, Wake C, Huntington TG, Luo L and others (2007) Past and future changes in climate and hydrological indicators in the U.S. Northeast. Clim Dyn 28:381-407

Held IM, Soden BJ (2000) Water vapor feedback and global warming. Annu Rev Energy Environ 25:441-475

Hodgkins GA, Dudley RW (2005) Changes in the magnitude of annual and monthly streamflows in New England, 1902-2002. Report No. SIR 2005-5235, US Geological Survey Scientific Investigations, Reston, VA

Hopkins TS, Garfield N (1979) Gulf of Maine Intermediate Water. J Mar Res 37:103-139

Huntington TG (2006) Evidence for intensification of the global water cycle: review and synthesis. J Hydrol (Amst) 319:83-95

Huntington T (2010) Climate warming-induced intensification of the hydrologic cycle: an assessment of the published record and potential impacts on agriculture. In: Sparks D (ed) Advances in agronomy, Vol 109. Elsevier, New York, NY, p 1-51

Ji R, Davis CS, Chen C, Townsend DW, Mountain DB, Beardsley RC (2008) Modeling the influence of lowsalinity water inflow on winter-spring phytoplankton dynamics in the Nova Scotian Shelf-Gulf of Maine region. J Plankton Res 30:1399-1416

Karl TR, Melillo JM, Peterson TC (eds) (2009) Global climate change impacts in the United States. Cambridge University Press, New York, NY

$>$ Keim BD, Wilson A, Wake C, Huntington TG (2003) Are there spurious temperature trends in the United States Climate Division Database? Geophys Res Lett 30: 1404-1407

Keim BD, Fischer MR, Wilson AM (2005) Are there spurious precipitation trends in the United States Climate Division database? Geophys Res Lett 32:L04702 doi:10.1029/2004 GL016295

King AW, Dilling L, Zimmerman GP, Fairman DM and others (2007) The first state of the carbon cycle report (SOCCR): The North American carbon budget and implications for the global carbon cycle. US Climate Change Science Program and the Subcommittee on Global Change Research, Oak Ridge National Laboratory, Oak Ridge, TN

Kirk JTO (1994) Light and photosynthesis in aquatic ecosystems, 2nd edn. Cambridge University Press, New York, NY

- Laws EA, Redalie DG, Haas LW, Bienfang PK and others (1984) High phytoplankton growth and production rates in oligotrophic Hawaiian coastal waters. Limnol Oceanogr 29:1161-1169

Madsen T, Figdor E (2007) When it rains, it pours: Global warming and the rising frequency of extreme precipitation in the United States. Environment America Research \& Policy Center, Washington, DC

$>$ Meade RH, Emery KO (1971) Sea level as affected by river runoff, eastern United States. Science 173:425-428

Mobley CD (1994) Light and water: radiative transfer in nat- 
ural waters. Academic Press, New York, NY

Moller F (1963) On the influence of changes in $\mathrm{CO}_{2}$ concentration in air on the radiation balance of Earth's surface and on climate. J Geophys Res 68:3877-3886

Mountain DG, Manning JP (1994) Seasonal and interannual variability in the properties of the surface waters of the Gulf of Maine. Cont Shelf Res 14:1555-1581

O'Reilly JE, Busch DA (1984) Phytoplankton primary production on the northwestern Atlantic shelf. Rapp P-V Reun Cons Int Explor Mer 183:255-268

Peel MC, Finlayson BL, McMahon TA (2007) Updated world map of the Köppen-Geiger climate classification. Hydrol Earth Syst Sci 11:1633-1644

Pershing AJ, Hannah CG, Greene CH, Mountain DG and others (2001) Oceanographic responses to climate in the Northwest Atlantic. Oceanography 14:76-82

Peterson TC, Vose RS (1997) An overview of the Global Historical Climatology Network temperature database. Bull Am Meteorol Soc 78:2837-2849

Pettigrew NR, Townsend DW, Xue H, Wallinga JP, Brickley PJ, Hetland RD (1998) Observations of the Eastern Maine Coastal Current and its offshore extensions in 1994. J Geophys Res C 103:30623-30639

Pettigrew NR, Xue H, Irish JD, Perrie W, Roesler CS, Thomas AC, Townsend DW (2008) The gulf of Maine ocean observing system: generic lessons learned in the first seven years of operation (2001-2008). Mar Technol Soc J 42:91-102

Pettigrew NR, Patrick Fikes C, Kate Beard M (2011) Advances in the Ocean Observing System in the gulf of Maine: technical capabilities and scientific results. Mar Technol Soc J 45:85-97

Ramp SR, Schlitz RJ, Wright WR (1985) The deep flow through the Northeast Channel, Gulf of Maine. J Phys Oceanogr 15:1790-1808

Rampton VN, Gauthier RC, Thibault J, Seaman AA (1984) Quaternary geology of New Brunswick, Memoir 416. Geological Survey of Canada, Ottawa

Randall AD (1998) Mean annual runoff, precipitation, and evapotranspiration in the glaciated northeastern United States, 1951-1980. Report No. Open-File Report 96-395, US Geological Survey, Reston, VA

Raymond PA, Oh NH (2007) An empirical study of climatic controls on riverine $\mathrm{C}$ export from three major U.S. watersheds. Global Biogeochem Cycles 21:GB2022 doi: 10.1029/2006GB002783

Rial JA, Pielke RA Sr, Beniston M, Claussen M and others (2004) Nonlinearities, feedbacks and critical thresholds within the earth's climate system. Clim Change 65:11-38

Editorial responsibility: Katherine Richardson, Copenhagen, Denmark
Schmittner A, Weaver AJ (2001) Dependence of multiple climate states on ocean mixing parameters. Geophys Res Lett 28:1027-1030

> Smith PC, Houghton RW, Fairbanks RG, Mountain DG (2001) Interannual variability of boundary fluxes and water mass properties in the Gulf of Maine and on Georges Bank: 1993-1997. Deep-Sea Res II 48:37-70

Thomas AC, Townsend DW, Weatherbee R (2003) Satellitemeasured phytoplankton variability in the Gulf of Maine. Cont Shelf Res 23:971-989

Toppan FW (1935) The physiography of Maine. J Geol 43: 76-87

- Townsend DW, Pettigrew NR, Thomas AC (2005) On the nature of Alexandrium fundyense blooms in the Gulf of Maine. Deep-Sea Res II 52:2603-2630

Townsend DW, Rebuck ND, Thomas MA, Karp-Boss L, Gettings RM (2010) A changing nutrient regime in the Gulf of Maine. Cont Shelf Res 30:820-832

Trenberth KE, Jones PD, Ambenje P, Bojariu R and others (2007) Observations: surface and atmospheric climate change. In: Solomon S, Qin D, Manning M, Chen Z and others (eds) Climate Change 2007: The physical science basis. Contribution of Working Group I to the Fourth Assessment Report of the Intergovernmental Panel on Climate Change. Cambridge University Press, Cambridge, UK, and New York, NY, p 235-336

> Trombulak SC, Wolfson R (2004) Twentieth-century climate change in New England and New York, USA. Geophys Res Lett 31:L19202 doi:10.1029/2004GL020574

> Verity PG, Williams SC, Hong Y (2000) Formation, degradation, and mass:volume ratios of detritus derived from decaying phytoplankton. Mar Ecol Prog Ser 207:53-68

Vose RS, Peterson TC, Hulme M (1998) The Global Historical Climatology Network precipitation data set: version 2.0. Ninth Symposium on Global Change Studies, Namias Symposium on Status and Prospects for Climate Prediction. American Meteorological Society, Boston, MA, Phoenix, AZ, p 103-104

Walter MT, Wilks DS, Parlange JY, Schneider RL (2004) Increasing evapotranspiration from the conterminous United States. J Hydrometeorol 5:405-408

- Walther GR (2010) Community and ecosystem responses to recent climate change. Philos Trans R Soc Lond B 365: 2019-2024

Wetzel RG (1975) Organic carbon cycle and detritus. In: Limnology. W. B. Saunders., Philadelphia, PA, p 583-621

Xue H, Chai F, Pettigrew NR (2000) A model study of the seasonal circulation in the Gulf of Maine. J Phys Oceanogr 30:1111-1135

Submitted: June 22, 2011; Accepted: December 12, 2011 Proofs received from author(s): March 13, 2012 